NBSIR 75-791

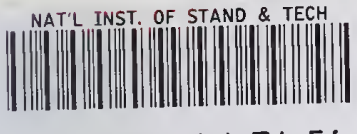

A2.21064 449456: :edural Options for

\title{
Modification of Architectural Glass in Residences to Improve Occupant Safety
}

S. Wayne Stiefel

Center for Consumer Product Technology Institute for Applied Technology National Bureau of Standards

Washington, D. C. 20234

December 1975

Final Report

Prepared for

Bureau of Engineering Sciences Sonsumer Product Safety Commission ¡401 Westbard Avenue 3ethesda, Maryland 20207 



\section{PROCEDURAL OPTIONS FOR MODIFICATION OF ARCHITECTURAL GLASS IN RESIDENCES TO IMPROVE OCCUPANT SAFETY}

S. Wayne Stiefel

Center for Consumer Product Technology Institute for Applied Technology

National Bureau of Standards

Washington, D. C. 20234

December 1975

Final

Prepared for

Bureau of Engineering Sciences

Consumer Product Safety Commission

5401 Westbard Avenue

Bethesda, Maryland 20207

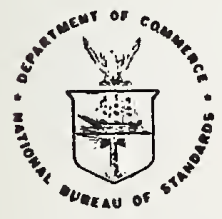

U.S. DEPARTMENT OF COMMERCE, Rogers C. B. Morton, Secretary James A. Baker, III, Under Socretery

Dr. Betsy Ancker-Johnson. Assistant Secretery for Sabnce and Tachnolesy 
Bin $\quad \therefore 0^{\circ}$

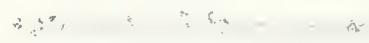




\section{Acknowledgment}

The author wishes to thank Mrs. Ruth Warnock for her assistance and patience in the preparation of this manuscript . 

Background

The U.S. Consumer Product Safety Commission (CPSC) has the responsibility for developing and promulgating mandatory safety standards for products which pose unreasonable risks of injury for consumers. One of the first products selected for development of a safety standard under the Consumer Product Safety Act of 1972 (CPSA) was architectural glass. The prospects for regulation of many other residential unit component parts are wide open. Nevertheless, the initial impact of the adoption of a mandatory standard for architectural glass would be rather limited. The limited impact is largely due to the fact that people will continue to occupy existing housing that will not be immediately subject to the new rule. Thus some attention must be given to steps that might be taken to reduce the risk to which these people are exposed.

Objective

The objectives of the project were to identify alternative retrofit options intended to ameliorate the hazards associated with existing installations of architectural glass, to evaluate the various options from the standpoint of accident reduction and associated costs, and finally to recommend, to CPSC, a set of feasible approaches to implement the most promising retrofit options.

Ana1ysis

Safety motivated modification of existing installations of architectural glass include the use of visual cues, barriers, replacement with safety glazing material, and application of organic coatings. These actions should be selectively applied to specific products based on their ability to: (1) ameliorate the hazard conditions contributing to injury; (2) perform effectively preventing the injury from being experienced, and (3) introduce no new types of injury potential of any significance.

A set of modifications was developed for specific products by reviewing in-depth accident reports and selecting modification concepts appropriate, depending upon the predominant set of circumstances associated with injuries. The architectural glass products for which retrofit approaches were developed included eight NEISS categories: bathtub and shower enclosures, prime windows, glass storm doors, glass panel (fixed window wal1), storm windows, jalousie glass doors, jalousied glass windows and glass doors (not otherwise specified).

A benefit-cost analysis of modifications for these products based upon averted injury medical costs yielded only one option which met the conventional decision point of 1.0 . This retrofit is the application of decals to patio sliding glass doors, which is at the point of indifference (benefit-cost very close to 1.0). Therefore, for a household which considers itself as having a higher risk than average, the application of decals would 
be warranted. Also for higher risk households, the replacement of the annealed glass lower panel of storm doors with hardboard might be considered, since its benefit-cost ratio was 0.85 . Additional analyses were performed to determine the magnitude of other factors, e.g., averted injuries not treated in emergency rooms, allowances for "pain and suffering," and avoided lost time from work, which would be necessary to improve the benefit-cost relationship sufficiently to justify recommendation of additional modifications. It is unlikely that these other factors would increase benefits sufficiently to justify additional modification options, since it was shown that quadrupling the calculated benefits would not achieve a 1.0 benefit-cost ratio.

Findings and Recommendation

The study found that in addition to the application of decals to patio sliding glassdoors, and possibly the replacement of annealed glass in the lower panel of storm doors with hardboard for high risk households, consumers should be encouraged to correct improper operation of all architectural glass products and to store unused glass panels out of traffic. For these recommendations the use of an informational and educational approach by the CPSC stands out among the implementation alternatives considered.

An informational campaign could bring to the public's attention the hazards associated with storm doors and patio glass doors. A fact which might be emphasized during any such campaign is, for both patio sliders and storm doors, children are subjected to many more injuries than can be accounted for by population alone. Such emphasis would bring the problem to the attention of parents and alert them to the possibility that, although they "respect" these products, their children may not have knowledge of the hazard. The Commission should consider a dual approach to attempt implementation of safety modifications by consumers through both information dissemination and education efforts.

Any education effort must recognize that the problem involves alerting children and adults to the proper approach for using architectural glass products. Adults must be influenced to make the necessary safety modifications, and they must be given adequate information with which to make products safer. In addition to efforts designed to educate the general public, some effort is warranted to educate the editors of interior design and home-oriented magazines. Articles illustrating attractive decoration of patio sliders with decals could contribute toward consumer acceptance of this idea. 
Contents

Page

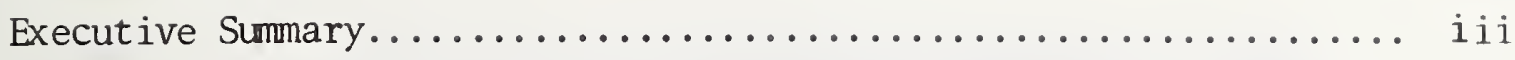

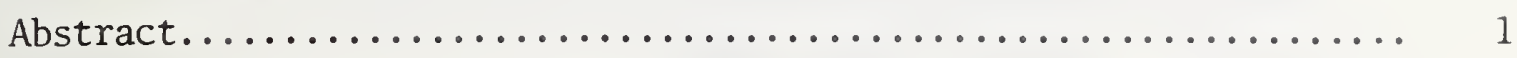

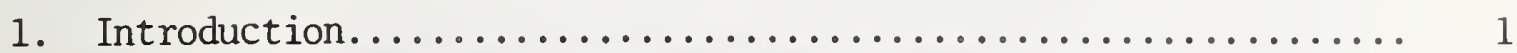

1.1. Project Background........................... 1

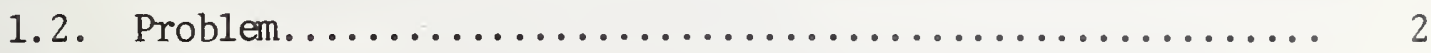

1.3. Objectives and Scope of Project................... 3

1.4. Description of Report Contents................... 3

2. Architectural Glass Injury Data Analysis............... 4

2.1. NEISS Data and Analysis........................ 4

2.2. Population of Annealed Architectural Glass Products..... 8

2.3. Relation of Injuries to Population of Products......... 8

3. Modification Options Suggested by Accident Pattern Review..... 12

3.1. Effectiveness of Safety Modifications in Reducing

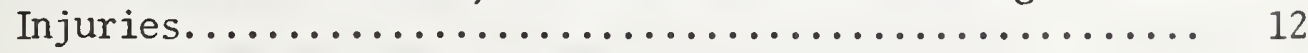

3.1.1. Amelioration of Hazard Pattern............ 12

3.1.2. Performance of Retrofit Alternatives......... 13

3.1.3. Potential Retrofit Injury Causation.......... 16

3.2. Retrofits Developed from In-Depth Investigations....... 16

3.2.1. Bathtub and Shower Enclosures............. 16

3.2.2. Window and Window Glass Other Than Storm Windows. 17

3.2.3. Glass Storm Doors (Annealed Glass)........... 18

3.2.4. Glass Panel, Fixed (Window Walls).......... 19

3.2.5. Glass Panels, Sliding (Patio Doors).......... 19

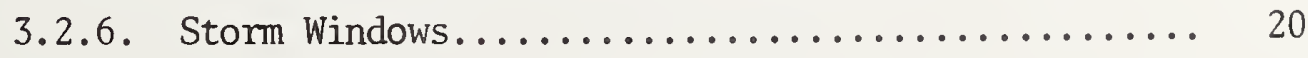


Contents (continued)

Page

3.2.7. Jalousie Glass Doors ................ 20

3.2.8. Jalousie Glass Windows $\ldots \ldots \ldots \ldots \ldots \ldots \ldots$

3.2.9. Glass Doors, Not Otherwise Specified ....... 21

4. Benefit-Cost Mode1 .......................... 22

4.1. Benefit of Averted Medical Injury Costs ......... 22

4.2. Cost Derivation for Retrofits ................ 23

4.3. Computation of Benefits for Retrofits ........... 24

4.4 Analysis of Benefit-Cost Derivation ............. 28

4.5 Approaches for Encouraging

Architectural Glass Safety .................. 31

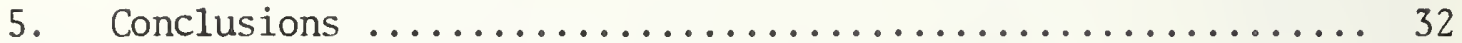

Appendix A. Derivation of Population Estimates for

Annealed Glass Products ..................... A-1

Appendix B. Derivation of the Benefit Equation and

Computation of Averted Injury Medical Costs ...... B-1

Appendix C. Implementation Approaches for Encouraging

Safety Modification of Hazardous Architectural

Glass Products ........................ -1 
Table 2.1.1. NEISS Matrix Report Injury Totals by Age Group, Sex and Selected Injury Types (7/1/72-12/31/74)....

2.1.2. Projection of NEISS Architectural Glass Data to All Hospital Emergency Rooms for a One-Year Period...... 6

2.1.3. Percentages of Injuries for Each Architectural Glass

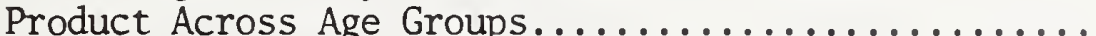

2.1.4. Relative Indices of the Ratios of NEISS Injury Percentages Divided by the General Population Percents for Each Architectural Glass Product by Age Group.... 9

2.2. Estimates of Annealed Glass Products.............. 10

2.3. Estimated Annual Injuries in All Hospital Emergency Rooms per Product for Architectural Glass Products... 11

3.1.1. Use of Modification Concepts to Ameliorate Injury Circumstances........................... 14

4.2. Estimated Costs for Product Specific Retrofits...... 25

4.3.1. Data for Annealed Glass Products Required to Compute Benefits.............................. 26

4.3.2. Calculated Averted Injury Medical Costs Attributable

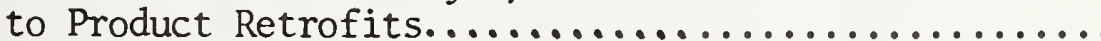

4.4.1. Estimated Benefit-Cost Ratios for Product Specific

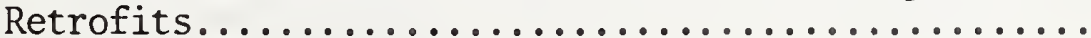

4.4.2. Additional Analysis for Product Specific Retrofits: Multiplier of Benefit-Cost Value to Achieve 1.0 Benefit-Cost........................... 30

B. Computation of Benefit Derived from Averted Medical Injury Costs Using a 10 Percent Discount Rate over a Fifty Year Period....................... B-4

C. Potential Implementation Approaches for Safety Modification of Architectural Glass Products........ 



\section{S. Wayne Stiefe1}

The U.S. Consumer Product Safety Commission has the responsibility for developing and promulgating mandatory safety standards for products which pose unreasonable risks of injury for consumers. One of the first products selected for development of a safety standard under the Consumer Product Safety Act of 1972 was architectural glass. The prospects for regulation of many other residential unit component parts are wide open. Nevertheless, the initial impact of the adoption of a mandatory standard for architectural glass would be rather limited. The limited impact is largely due to the fact that people will continue to occupy existing housing that will not be immediately subject to the new rule.

This report documents the second and final phase of a project which considered the possible modifications for architectural glass products and the means for encouraging their implementation. The report evaluates available injury data, defines the population of hazardous architectural glass products and compares the relative level of hazard among the products. A set of possible retrofit options is presented, suggested by accident pattern review, and criteria are developed, which are useful in assessing their effectiveness. A model has been developed and exercised to calculate benefit-cost ratios for retrofit modification based upon averted injury medical costs attributable to injuries prevented by product modification. A set of implementation approaches has been postulated for consideration by the CPSC, for encouraging safety modifications of component parts of residential units.

Key words: Architectural glass products; Consumer Product Safety Act; residence-related products; residential safety modification; safety implementation approaches.

\section{INTRODUCTION}

\subsection{Project Background}

The use of sliding glass doors by the building industry has been increasing since their introduction in the 1940 's. The very appearance of spaciousness created by glazing panels, which increase their demand as a building material, unfortunately contributes to the likelihood of unexpected contact. The Consumer Product Safety Commission (CPSC) estimated that in 1973, 180 thousand persons sought medical treatment in hospital emergency rooms for injuries associated with architectural glass.

\footnotetext{
${ }^{1}$ Based on a projection of the National Electronic Injury Surveillance System statistics.
} 
Previous surveys reveal additional factors associated with architectural glass injuries. Glass doors and windows were involved in 25 percent of all home fixture accidents, according to the 1969 survey by Teledyne Brown Engineering. ${ }^{2}$ A 1963 glass door survey, for the Public Health Service, indicated that about three-quarters of the reported injuries occurred in the home. Further analysis of the NEISS data (collected from July 1972 to January 1974) indicates that 40 percent of injured persons admitted to hospital emergency rooms are under fifteen years of age (this age group accounts for 27 percent of the population) and approximately 60 percent of persons admitted are males.

The CPSC effort to develop and promulgate a regulation for architectural glazing follows several significant attempts to establish a voluntary standard for safety glazing, and to promote mandatory use of the ANSI standard for architectural glazing at the state level. ${ }^{3}$ This standard was developed to approve safety glazing of various types and fail annealed glass; it was modified and made more rigorous in 1972. Another recent effort is that of the Consumer Safety Glazing Committee (formed in 1969 during the hearings of the National Commission on Product Safety and consisting of representatives from glass manufacturers, fabricators and representatives of affected unions) which developed a Mode1 Bill to Require Safety Glazing in Hazardous Locations. This bill, intended for enactment by state legislatures, references ANSI Standard 2-97.1-1972, and is applicable to "hazardous locations in residential, industrial, commercial and public buildings." Albeit slow, progress is being made; as of May 1974, 32 states, representing 75 percent of the U.S. population, had adopted a mandatory code or law which incorporates ANSI Z-97.1-1972.4

\subsection{Problem}

The CPSC is now reviewing a proposed standard for architectural glazing developed by the Consumer Safety Glazing Committee, under the procedures of Section 7 of the Consumer Product Safety Act. The Commission may promulgate a standard in the near future applicable to glazing materials used in new or replacement architectural products, and although this action is intended to decrease the incidence and severity of injuries caused by architectural glazing, its initial impact will be rather limited. This is largely due to the fact that people will continue to occupy existing housing that will not be immediately subject to the new rule.

${ }^{2}$ Teledyne Brown Engineering, A Design Guide for Home Safety, PB-211709, January 1972.

${ }^{3}$ The American National Standards Institute developed and published ANSI Z-97.1, Performance Specifications and Methods of Test for Transparent Safety Glazing Materials Used in Buildings" in 1966.

${ }^{4}$ Sanford C. Adler and R. Tibbot, "Background Report on Architectural Glass," NBS Interagency Communication, June 28, 1974, p. 20. 
The National Commission on Product Safety recognized that product safety standards for architectural glass products would not ameliorate the hazards for existing homes. 5

"The glass door is a classic example of a product which will be 'misused.' As misuse is foreseeable and the danger avoidable, the risk is unreasonable. The millions of panels of annealed glass now in use, unfortunately, are an endemic menace which grows yearly because, with age, annealed glass becomes weaker. Even if new construction complies with such state or local standards as now exist, the residual hazard in annealed glass already installed will persist for many years."

Adler ${ }^{6}$ speculates that the initial effect of a CPSC architectural glass standard may in fact increase injuries.

"If consumer expectations of safety glazing performance are applied to older glazing materials, the number of glass related injuries may increase. Individuals may treat existing glazing less cautiously as they are more frequently exposed to safety glazing."

Therefore, efforts aimed at decreasing the incidence and severity of injuries caused by architectural glass must address both the obvious and obtuse hazards associated with glazing materials in existing residences.

Fortunately, there are retrofit options for annealed glass products which will reduce both accident occurrence and injury severity once an accident occurs. These options have been available to consumers but have achieved a very limited use. The Commission requires a set of alternative actions which will result in increased public awareness of the architectural glass problem, with a corresponding interest in taking appropriate preventive measures.

\subsection{Objectives and Scope of Project}

The objectives of the project were to identify alternative retrofit options intended to ameliorate the hazards associated with existing installations of architectural glass, to evaluate the various options from the standpoint of accident reduction and associated costs, and finally to recommend, to CPSC, a set of feasible approaches to implement the most promising retrofit options.

\subsection{Description of Report Contents}

This report documents the second and final phase of project work and deals with each of the project objectives as described above. Section 1 of this report outlines the project's background and scope. Section 2 evaluates the injury data, defines the population of architectural

${ }^{5}$ Final Report of the National Conmission on Product Safety, June 1970, p. 13. ${ }^{6}$ Adler, op. cit., p. 164. 
glass products, and compares the relative level of hazard among the products. Section 3 presents retrofit options suggested by accident pattern review and develops criteria useful in assessing effectiveness in reducing injuries. Section 4 discusses a model for calculating a benefit-cost ratio for retrofit modifications. Benefits are defined as potentially averted injury medical costs attributable to injuries prevented by product modifications. Section 5 identifies implementation approaches for consideration by the CPSC, which are appropriate for encouraging safety modifications of architectural glass products.

\section{ARCHITECTURAL GLASS INURY DATA ANALYSIS}

\subsection{NEISS Data and Analysis}

The Commission's National Electronic Injury Surveillance System (NEISS) was the major source of data for the analyses which follow. Table 2.1.1. summarizes data collected from July 1972 through December 1974 for the following nine product categories of architectural glass: bathtub and shower enclosures, window and window glass, glass storm doors, glass panels (fixed), glass panels (sliding), storm windows, jalousie glass doors, jalousie glass windows and glass doors (not otherwise specified).

It is obvious from the data that windows and window glass (prime windows) products account for more than half of all the injuries related to architectural glass (as reported by NEISS). This product category contributes to injuries at a rate of almost four times as much as the next highest ranking product--glass storm doors, and over five times as much as the third highest product category--glass doors, not otherwise specified.

Of course, the NEISS totals apply only to those emergency rooms participating in the surveillance program. The CPSC's Bureau of Epidemiology has, by applying weighting factors to the various hospital emergency room reports, made projections of total hospital emergency room cases. These results are presented in Table 2.1.2.

Architectural glass product injury data was examined to determine injury incidence by age and sex. Table 2.1 .3 presents the percentages of injuries associated with these nine products, broken down by the indicated age groups. These age groupings are similar to those given in the NEISS Matrix Report Summaries covering the $21 / 2$ year period July 1, 1972 to December 31, 1974. ${ }^{7}$ The percentages in the body of Table 2.1.3 were derived from these summaries and were used, in conjunction with comparable statistics based upon the number of people in the general population, to establish ratio indices for the different age groups and products.

${ }^{7}$ It was necessary to pool the lowest two age groups (0-2 and 2-4) to match the available population data given at less than 5 . 
Table 2.1.1. NEISS Matrix Report Injury Totals by Age Group, Sex and Selected Injury Types (7/1/72 - 12/31/74)

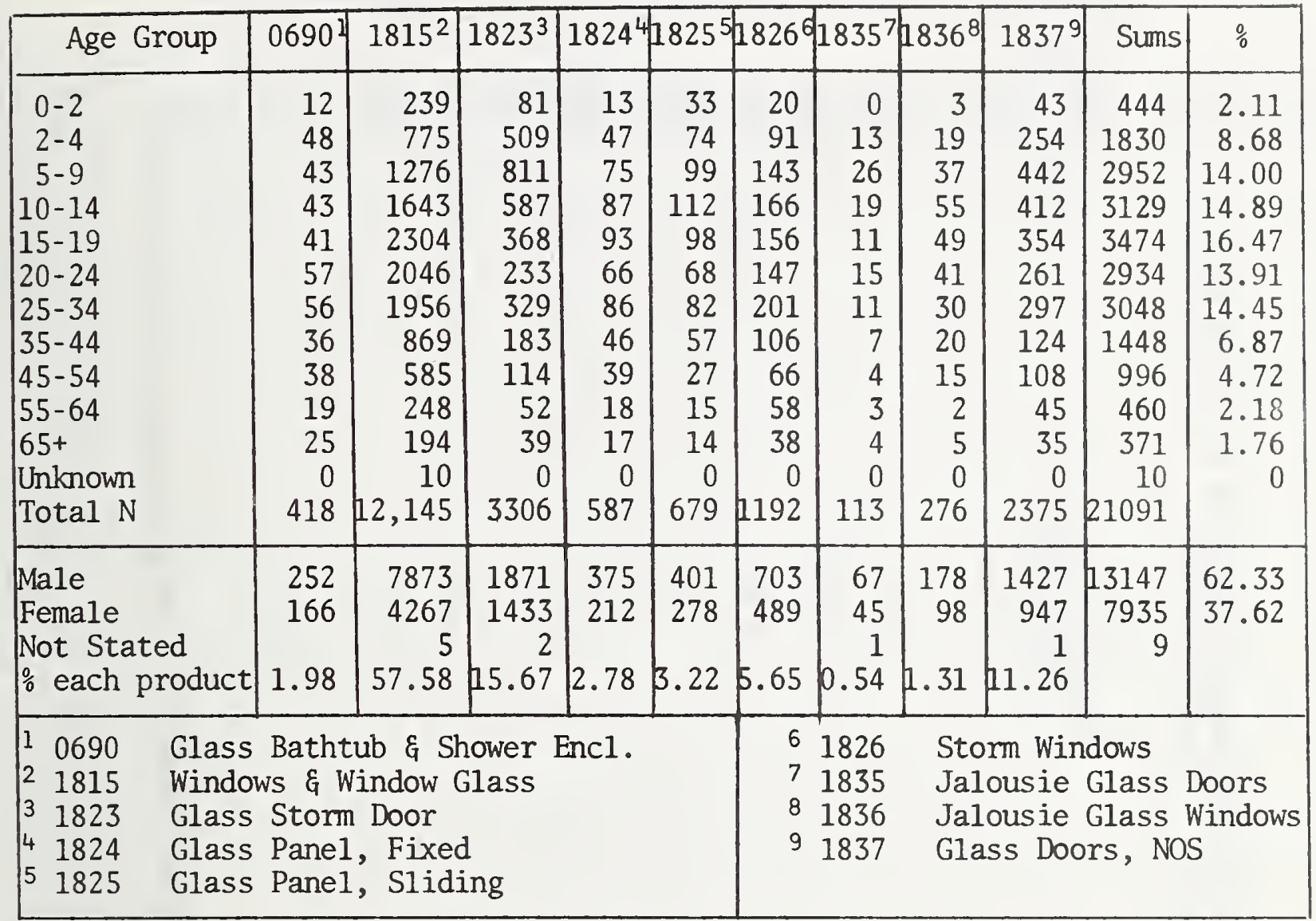




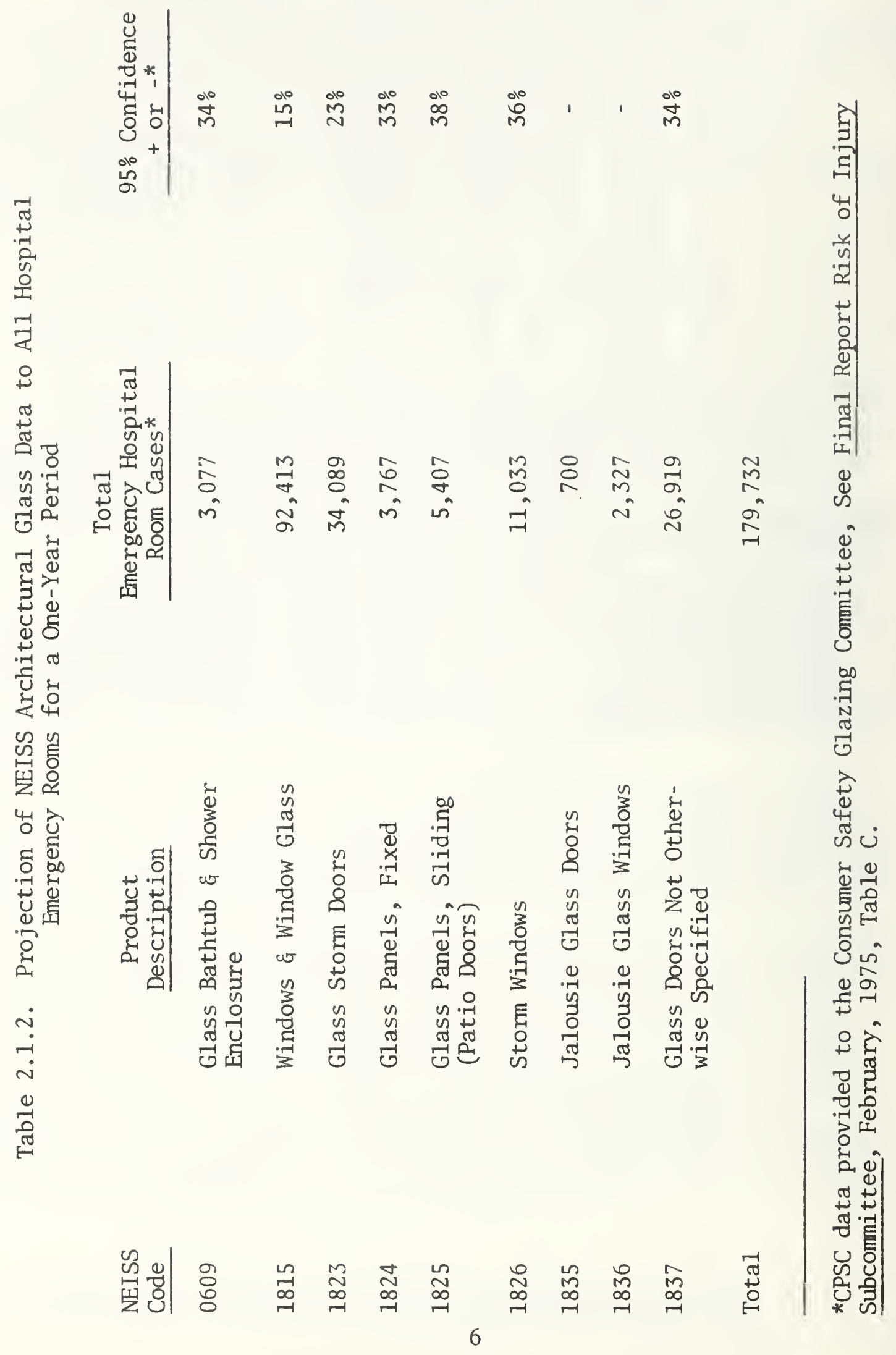


Table 2.1.3. Percentages of Injuries for Each Architectural Glass Product Across Age Groups

(NEISS Matrix Report Data: 7/1/72 - 12/31/74)

\begin{tabular}{|c|c|c|c|c|c|c|c|c|c|c|}
\hline $\begin{array}{l}\text { Age } \\
\text { Group }\end{array}$ & 06091 & $1815^{2}$ & $1823^{3}$ & $\begin{aligned} \text { Proc } \\
1824^{4}\end{aligned}$ & $\frac{\text { luct Cr }}{1825^{5}}$ & $\frac{\text { odes }}{11826^{6}}$ & $1835^{\prime}$ & $1836^{8}$ & $1837^{9}$ & $\begin{array}{l}\text { Percent of } \\
\text { Total Population* }\end{array}$ \\
\hline$<5$ & 14.35 & 8.35 & 17.85 & 10.22 & 15.76 & 9.31 & 11.50 & 7.97 & 12.51 & 8.42 \\
\hline $5-9$ & 10.29 & 10.51 & 24.53 & 12.78 & 14.58 & 12.00 & 23.01 & 13.41 & 18.61 & 9.87 \\
\hline $10-14$ & 10.29 & 13.53 & 17.76 & 14.82 & 16.49 & 13.93 & 16.81 & 19.93 & 17.35 & 10.26 \\
\hline $15-19$ & 9.81 & $|18.97|$ & 11.13 & 15.84 & 14.43 & 13.09 & 9.73 & 17.75 & 14.91 & 9.45 \\
\hline $20-24$ & 13.64 & 16.85 & 7.05 & 11.24 & 10.01 & 12.33 & 13.27 & 14.86 & 10.99 & 7.93 \\
\hline $25-34$ & 13.40 & 16.11 & 9.95 & 14.65 & 12.08 & 16.86 & 9.73 & 10.87 & 12.51 & 12.23 \\
\hline $35-44$ & 8.61 & 7.16 & 5.54 & 7.84 & 8.39 & 8.89 & 6.19 & 7.25 & 5.22 & 11.38 \\
\hline $45-54$ & 9.09 & 4.82 & 3.45 & 6.64 & 3.98 & 5.54 & 3.54 & 5.43 & 4.55 & 11.39 \\
\hline $55-64$ & 4.55 & 2.04 & 1.57 & 3.07 & 2.21 & 4.87 & 2.65 & .72 & 1.89 & 9.18 \\
\hline $65^{+}$ & 5.98 & 1.60 & 1.18 & 2.90 & 2.06 & 3.19 & 3.54 & 1.81 & 1.47 & 9.89 \\
\hline Male & $60.29 \mid$ & 64.85 & 56.63 & 63.88 & 59.06 & 58.98 & 59.82 & 64.49 & 60.11 & 48.66 \\
\hline Female & 39.71 & 35.15 & 43.37 & 36.12 & 40.94 & 41.02 & 40.18 & 35.51 & 39.89 & 51.34 \\
\hline Total N & 418 & 12,155 & 3,306 & 587 & 679 & 1,192 & 113 & 276 & 2,375 & 21,091 \\
\hline $\begin{array}{ll}1 & 0690 \\
2 & 1815 \\
3 & 1823 \\
4 & 1824 \\
5 & 1825\end{array}$ & \multicolumn{5}{|c|}{$\begin{array}{l}\text { Glass Bathtub \& Shower Encl. } \\
\text { Windows \& Window Glass } \\
\text { Glass Storm Door } \\
\text { Glass Pane1, Fixed } \\
\text { Glass Panel, Sliding }\end{array}$} & \multicolumn{4}{|c|}{$\begin{array}{ll}6 & 1826 \\
7 & 1835 \\
8 & 1836 \\
9 & 1837\end{array}$} & $\begin{array}{l}\text { S Doors } \\
\text { s Windows } \\
\text { NOS }\end{array}$ \\
\hline
\end{tabular}

*U.S. Bureau of the Census, Census of Population 1970, General Social and Economic Characteristics Final Report, PC(1)-CL, United States Summary, Table 85. 
The values in Table 2.1.4 were obtained by dividing the percent in each cell of Table 2.1.3 by the percent of the corresponding age group. The resultant quotients of these ratios provided a relative indication of the relationship between the NEISS sample population and the general population. For any given product and given age group, if the proportion of injured people is the same as the proportion of people in that same age group for the general population, then the index will be 1.0 . Values larger than 1.0 indicate a higher proportion in the sample than in the general population for the same group. Values less than 1.0 indicate the converse. The magnitude of the index denotes its relative seriousness.

\section{A cursory examination of Table 2.1 .4 reveals that, in general,} injuries involving architectural glass products tend to be more prevalent among males and among people under 25 years of age.

\subsection{Population of Annealed Architectural Glass Products}

Since 1971 various states have implemented controls over the use of annealed glass in "hazardous locations," including entrance and exit doors, storm doors, and bathtub/shower enclosures. ${ }^{8}$ Unfortumately the ability to accurately estimate the number of products in use, and to differentiate between annealed glass and tempered or other safety glazing is difficult. The estimates which follow are documented in Appendix A and have been principally based upon an analysis of the estimates made by the Architectural Glass Project's Consumer Safety Glazing Committee Economic and Environmental Subcommittee's Final Report of February, 1975. The subcommittee's sources included Census Bureau reports on construction, surveys performed for various industries and estimates from several trade associations.

A ranking of the number of architectural products containing annealed glass, in Table 2.2 places prime windows first, followed by storm windows, entrance/exit doors, storm doors, patio sliding doors and finally bathtub and shower enclosures. Estimates were not found for fixed glass panels, jalousie glass doors or jalousie windows used in residential units.

\subsection{Relation of Injuries to Population of Products}

It has been pointed out that prime windows account for we11 over half of the injuries sustained from architectural glass products. A measure of injuries per product would provide an additional perspective into the problem. Table 2.3 was derived from Table 2.2, Estimate of Annealed Annealed Glass Products, and Table 2.1.5, Projection of NEISS Architectural Glass Data to All Hospital Emergency Rooms. Table 2.3 includes only those products which are predominately found in the home. Products for which no population estimates were available were excluded. Bathtub and shower enclosures have the highest value in terms of injuries per product,

\footnotetext{
${ }^{8}$ Approximately 80 percent of the U.S. population resides in states which have adopted safety glazing legislations or made it a requirement in mandatory state codes.
} 
Table 2.1.4. Relative Indices of the Ratios of NEISS Injury Percentages Divided by the General Population Percents for Each Architectural Glass Product by Age Group

\begin{tabular}{|c|c|c|c|c|c|c|c|c|c|}
\hline \multirow{2}{*}{$\begin{array}{l}\text { Age } \\
\text { Group }\end{array}$} & \multicolumn{9}{|c|}{ Product Codes } \\
\hline & 06091 & $1815^{2}$ & $1823^{3}$ & $1824^{4}$ & $1825^{5}$ & $1826^{6}$ & $1835^{\prime}$ & $1836^{8}$ & $1837^{9}$ \\
\hline$<5$ & 1.70 & .99 & 2.12 & 1.21 & 1.87 & 1.11 & 1.37 & .95 & 1.49 \\
\hline $5-9$ & 1.04 & 1.06 & 2.49 & 1.29 & 1.48 & 1.22 & 2.33 & 1.36 & 1.89 \\
\hline $10-14$ & 1.00 & 1.32 & 1.73 & 1.44 & 1.61 & 1.36 & 1.64 & 1.94 & 1.69 \\
\hline $15-19$ & 1.04 & 2.01 & 1.18 & 1.68 & 1.53 & 1.39 & 1.03 & 1.88 & 1.58 \\
\hline $20-24$ & 1.72 & 2.12 & .89 & 1.42 & 1.26 & 1.55 & 1.67 & 1.87 & 1.39 \\
\hline $25-34$ & 1.10 & 1.32 & .81 & 1.20 & .99 & 1.38 & .80 & .89 & 1.02 \\
\hline $35-44$ & .75 & .63 & .49 & .69 & .74 & .78 & .54 & .64 & .46 \\
\hline $45-54$ & .80 & .42 & .30 & .58 & .35 & .47 & .31 & .48 & .40 \\
\hline $55-64$ & .50 & 1.31 & .17 & .33 & .24 & .53 & .29 & .08 & .20 \\
\hline $65+$ & .60 & .16 & .12 & .29 & .21 & .32 & .36 & .18 & .15 \\
\hline Male & 1.24 & 1.33 & 1.16 & 1.31 & 1.21 & 1.21 & 1.23 & 1.32 & 1.23 \\
\hline Female & .77 & .68 & .84 & .70 & .80 & .80 & .78 & .69 & .73 \\
\hline $\begin{array}{ll}1 & 0690 \\
2 & 1815 \\
3 & 1823 \\
4 & 1824 \\
5 & 1825\end{array}$ & $\begin{array}{l}\text { Glass } \\
\text { Window } \\
\text { Glass } \\
\text { Glass } \\
\text { Glass }\end{array}$ & $\begin{array}{l}\text { thtub } \\
\text { \& Wind } \\
\text { orm Do } \\
\text { ne1, F } \\
\text { nel, S }\end{array}$ & $\begin{array}{l}\text { Shower } \\
\text { Glass }\end{array}$ & c1. & $\begin{array}{ll}6 & 1 \\
7 & 1 \\
8 & 1 \\
9 & 1\end{array}$ & $\begin{array}{ll}6 & \text { Sto } \\
5 & \mathrm{Ja} 1 \\
6 & \mathrm{Jal} \\
7 & \mathrm{Gla}\end{array}$ & $\begin{array}{l}\text { Windo } \\
\text { sie Gl } \\
\text { sie G1 } \\
\text { Doors }\end{array}$ & $\begin{array}{l}\text { S Door } \\
\text { s Wind } \\
\text { NOS }\end{array}$ & \\
\hline
\end{tabular}




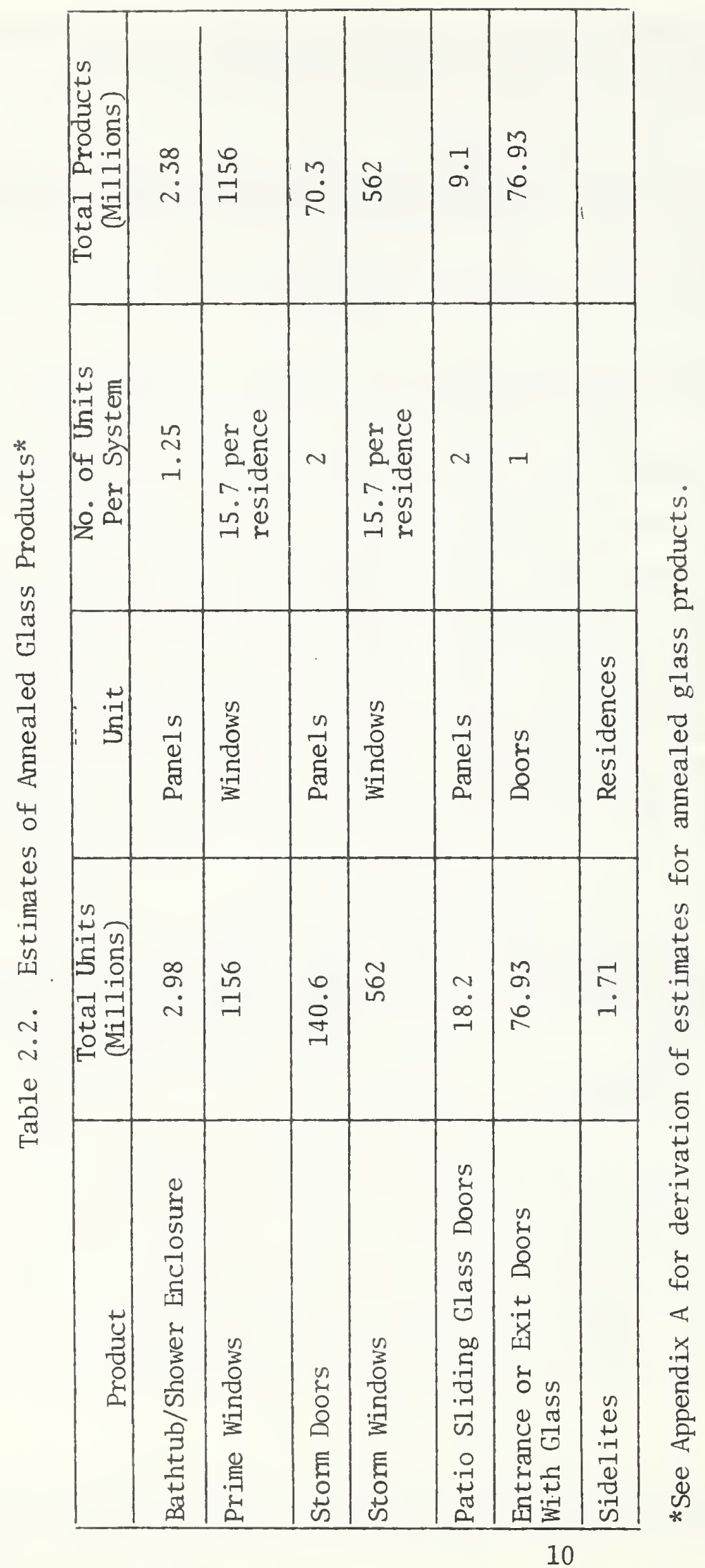


Table 2.3. Estimated Annual Injuries in All Hospital Fmergency Rooms per Product for Architectural Glass Products

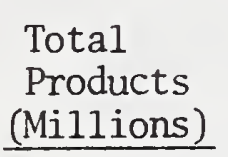

Bathtub/Shower

Enclosures

Prime Windows

Storm Doors

Glass Panels, Sliding Patio Doors

Storm Windows

2.38

1,156

70.3

9.1

562
Estimated Annual Injuries per Product (x1000)

0.080

0.062

0.485

0.375

0.594

0.460

$$
1.000
$$

1.293* per Product with Bathtub/ Shower Enclosures 
more than twice that occurring for the next highest product, patio sliding glass. The last column of Table 2.3 cormares injuries per product for each of the products with bathtub and shower enclosures.

Depending upon the objectives of the Commission, Table 2.3 serves to illustrate that different emphasis would be placed upon efforts to reduce injuries associated with these products. For example, if total numbers of injuries were the basis for selection, then clearly prime windows would be the major candidate. However, if the incidence of injury per product was the criteria selected, bathtub/shower enclosures, when compared to prime windows, account for about sixteen times as many injuries per product.

\section{MODIFICATION OPTIONS SUGGESTED BY ACCIDENT PATTERN REVIEW}

\subsection{Effectiveness of Safety Modifications in Reducing Injuries}

A recommendation to utilize a specific safety retrofit for an architectural glass product would depend upon satisfying three basic criteria for evaluating safety effectiveness:

(1) that the retrofit concept ameliorates the hazard pattern or circumstances responsible for injury or death;

(2) that the product after retrofit actually performs in a safer manner (effectively preventing experienced injury patterns); and

(3) that the retrofit, although preventing the type of injury previously being experienced, does not introduce a significant number of new types of injuries.

The modifications for architectural glass products can be grouped into four categories:

(1) visual cues to call attention to the existence of the glass thus reducing the risk of unexpected contact;

(2) coatings (painted on or applied films) which either strengthen the glass or hold glass fragments together if breakage occurs;

(3) barriers such as screens or bars to restrict direct contact with the glass; and

(4) replacement of annealed glass with safety glazing materials or non-glazing materials.

\subsubsection{Amelioration of Hazard Pattern}

The selection of the retrofit concept appropriate for an architectural glass product depends upon the predominant set of circumstances associated with the injuries. For example, injuries resulting from a slip or fall could probably not have been prevented through increased glass visibility. Barriers to keep a person away from the glass surface would probably prevent such injury, or at least result in a less severe injury. Tempered glass would have a similar effect. Patio sliding doors or window walls, on the other hand, seem to provide accident circumstances 
where in many circumstances additional visual cues alert the person that the glass was present, thus averting injury.

Table 3.1.1 matches architectural glass products with appropriate modification concepts. Where "yes" is indicated, the in-depth reports provided a subjective basis to believe that the injury circumstances can be modified by the retrofit classification to significantly lower the level of injuries. The concept of changing the physical characteristics of the glass product, so that it breaks at the higher energy levels and after breaking presents a less hostile edge for cutting or penetrating, is represented by both of the retrofit concepts of coatings and the replacement with safety glazing. There seems to be general agreement that the concept of safer break characteristics is the most effective measure in preventing injuries. The architectural glass standard, under development, bases its rationale upon this concept, and, as Table 3.1.1 indicates all architectural glass products could effectively utilize these approaches. ${ }^{9}$

The use of barriers would also be effective for all products except storm windows or prime windows. The barriers would significantly interfere with the windows' function either by reducing light transmitted or by impairing operation.

Visua1 cues provide an appropriate preventive concept for fixed glass panels, sliding patio doors and doors which are predominantly glass. These products are involved in accident sequences in which often the injured person does not perceive the product's presence.

\subsubsection{Performance of Retrofit Alternatives}

The ability to quickly perceive a glass barrier would reduce injuries for products such as patio doors, fixed glass walls and predominantly glass doors. Such visual cues can be provided by the simple addition of decals at eye height for both adults and children. More complex schemes could use optical effects such as lighting or possible distortion of the glass only when the person is in motion. An evaluation of what fraction of the injuries could be prevented by increased visibility was not possible from examining the NEISS data. In-depth reports indicated that for those products mentioned, visibility was a factor in several of the accident occurrences.

Barriers to prevent the transfer of a person's kinetic energy to the architectural glass product appears to be an effective measure to reduce injuries. The barriers, however, must be designed to account for children as well as adults and must prevent circumstances where body parts are diverted over or under a barrier into the glass. Again, no statistical evidence is available to support the use of barriers.

${ }^{9}$ See Section 1.1 of the proposed "Safety Standard for Glazing Materials Used in Certain Architectural Products," January, 1975. 
Table 3.1.1. Use of Modification Concepts to Ameliorate Injury Circumstances

\begin{tabular}{|c|c|c|c|c|}
\hline Architectural Glass Product & $\begin{array}{l}\text { Visual } \\
\text { Cues }\end{array}$ & Coatings* & Barriers & $\begin{array}{l}\text { Replace With } \\
\text { Safety Glazing }\end{array}$ \\
\hline Bathtub/Shower Enclosures & no & yes & yes & yes \\
\hline Window \& Window Glass & no & yes & no & yes \\
\hline Glass Storm Doors & no & yes & yes & yes \\
\hline Glass Panels, Fixed & yes & yes & yes & yes \\
\hline $\begin{array}{l}\text { Glass Panels, Sliding } \\
\text { Patio Doors }\end{array}$ & yes & yes & yes & yes \\
\hline Storm Windows & no & yes & no & yes \\
\hline Jalousie Glass Doors & no & yes & yes & yes \\
\hline Jalousie Glass Windows & no & yes & yes & yes \\
\hline $\begin{array}{l}\text { Glass Doors Not Otherwise } \\
\text { Specified }\end{array}$ & yes & yes & yes & yes \\
\hline Doors with Some Vision Panel & no & yes & yes & yes \\
\hline
\end{tabular}

*Assuming coatings to provide additional strength to the glass when broken do not allow penetration of the body part or if penetration occurs do not cause more damage than annealed glass alone. 
The use of safety glazing materials, such as tempering, imbedding wire, organic coating, or lamination, as a replacement for annealed glass would significantly reduce injuries. 10 The effectiveness would of course depend upon the performance characteristics of the material selected; the ability to withstand impact and resistance to shattering. These characteristics vary among safety glazing material. It is assumed that any recommended replacement material would meet the standards established for new installations being developed by CPSC for glazed architectural products.

Organic coatings applied over annealed glass have been used widely to stop flying glass after explosions. More recently, claims have been made that organic-coated glass has injury preventing safety properties when persons impact the product. Organic glass is available with coatings already applied to annealed glass, ready to cut to size and install. Also, organic coatings are available in sheets of mylar which can either be applied professionally or on a do-it-yourself basis and as paint-on plastic coatings. The application of either mylar films or paint-on plastics has particular appeal as a retrofit option since the glass would probably not have to be removed from its frame.

However, very limited tests of mylar coatings performed at NBS proved to be inconclusive. The coatings appeared to work well when it remained adhered to the glass, but during some tests the coating separated from the glass and did not hold the glass fragments in place. Other tests indicated that in instances where a penetration does occur, there is a likelihood that the jagged fragments held by the coating may entrap the body member making extraction difficult or impossible without additional injury. Some glass breaking tests using simulated arm and other tests using a lead shot-filled punching bag impactor, showed that this phenomena actually did occur.

Therefore, additional information is needed to assess the effectiveness of organic coatings. Investigations are required to establish:

(1) How much of an increase in breaking resistance is provided to the glass (of several representative thicknesses)?

(2) What are the break patterns at energy levels just sufficient to break the glass?

(3) What are the break patterns and entrapment characteristics at increasing energy levels?

(4) What are the factors involved in "successfully" applying the organic coatings? and

(5) How well do the coatings hold up under various types of environmental conditions, both in performing their safety function as well as optical degradation over time?

10 U.S. Consumer Product Safety Cormission, Bureau of Epidemiology, Hazard Analysis Injuries Involving Architectural Glass, November, 1974, p. 1. 


\subsubsection{Potential Retrofit Injury Causation}

In-depth investigations of accidents reported in NEISS have indicated that the handling of annealed glass materials has caused injury. Therefore, options incorporating replacement or coatings, which by their nature require glass handling, are potential injury producers. The ability among individuals to perform retrofits varies with their skill, background and training, as well as the particular tasks involved in performing the modification. The extent to which additional injuries might be produced by safety modification was not assessed in this report.

A controlled experiment to monitor the performance of retrofit tasks by individuals of varied skill levels may reveal a significant potential for injury. Results from such experiments could lead to hints for performing injury-free modifications or recommendation that only qualified professionals perform certain modifications. In addition to the production of injuries during safety related modification, injuries of another mode are possible following product modification. For example, tempered glass resists breakage and can absorb higher energy levels than annealed glass. The individual who falls and strikes his head on tempered glass will probably avoid lacerations but may sustain impact type injuries, such as fractures, contusion or concussion.

There exists potential abuse which could result from a CPSC recommendation to use a safety retrofit. Those retrofits which do not reduce injury could cause consumers to (1) spend money needlessly, (2) subject themselves to the haizard of installing an ineffective retrofit, or (3) install a product which could result in a more hazardous annealed glass product following retrofit installation. To reduce the likelihood of such occurrences the Commission could require that products which are intended to improve safety properties of annealed glass be required to meet a set of standards established by the Commission.

\subsection{Retrofits Developed from In-Depth Investigations}

In-depth investigation reports provide insights into the sequence of actions resulting in an injury. Although they do not facilitate a statistically valid explanation of all NEISS injuries, the in-depths do report on the circumstances surrounding accidents and give information necessary to take corrective action. The modification options which follow were suggested by reviewing the in-depth reports and combining this information with suggestions presented in the Teledyne Brown Engineering, A Design Guide for Home Safety and a draft NBS report to the CPSC, Making Your Doorways Safer. ${ }^{11}$ In most cases only one of the suggested options would be applied; however, in some circumstances several may be compatible.

\subsubsection{Bathtub and Shower Enclosures}

The NEISS data indicated that injuries sustained in bathtub and shower enclosure accidents were more severe than injuries

${ }^{11} \mathrm{C}$. Johnson and R. Wehrli, Making Your Doorways Safer, February 4, 1975. 
sustained from other architectural glass products. The in-depth reports indicated that most accidents occurred when a person slipped and fell against the enclosure, breaking the glass. In many instances the person received injury to many areas of the body. Table 2.1.4 indicated that children under 5, and adults between 20 and 25 years old sustained 75 percent more injuries than would be predicted by population statistics alone. Fifty-eight percent of all accidents occurred to persons under 25 (accounting for only 46 percent of the population). The following options are suggested:

(1) Replace all annealed glass with safety glazing.

(2) Paint on plastic coatings or apply adhesive mylar over the annealed glass.

(3) Install secure grab bars and non-slip tread surfaces in and around bathtub and shower.

(4) Replace annealed glass enclosure with a rod and shower curtain.

3.2.2. Window and Window Glass Other Than Storm Windows

The Bureau of Epidemiology's publication Hazard Analysis - Injuries Involving Architectural Glass, November 1974, listed a set of patterns identified with window injuries; these were:

- loss of balance

- intentional contact with window by opening or closing window; knocking or banging on windows

- contact with glass broken prior to accident, and

- accidents not involving broken glass

Table 2.1.4 indicates that persons 15 to 25 received twice as many injuries as their frequency in the population would indicate.

The Consumer Safety Glazing Committee did an analysis which indicated that increasing the energy required to break glass would substantially reduce injury incidence. "As we understand the results of the study (special in-depth study on windows and storm windows) the use of glazing material, which can withstand a $5 \mathrm{ft}$. 1b. impact would eliminate approximately 50 percent of the injuries, and the use of glazing material which can withstand an impact of $12 \mathrm{ft}$. 1bs. or more would eliminate approximately 75 percent of injuries associated with windows and storm windows."12

The following suggestions are intended to reduce accident occurrence, both for injuries which involve contact with glass as well as accidents not involving broken glass:

(1) Replace pitted, crazed or cracked glass with safety glazing or double strength glass.

12 Comments of A. J. Bartosic, Rohm and HAAS Company, Risk of Injury Subcommittee, meeting, January 16, 1975. 
(2) Correct any improper operation or installation;

- sticking

- need for more than usual force to open or close

- slamming shut

- loose or broken putty or moldings.

(3) Install lifting handles on bottom half of double-hung windows.

(4) Paint on plastic coating or apply adhesive mylar on annealed surface.

(5) Remove broken glass immediately from frame and dispose of properly. Do not leave in or around house.

\subsubsection{Glass Storm Doors (Annealed Glass)}

In-depth investigations of glass storm door injuries indicated the most common pattern of injury involved the opening or closing of the door. ${ }^{13}$ Accidents involved either pushing on the glass or following too closely behind another person and being struck by the door upon closing. Haste was a predominant factor in this type of occurrence. A second pattern involved loss of balance and tended to be more serious. Less common events included slamming the door, knocking on the glass and contacting glass that was already broken.

Referring to Table 2.1.3, it can be noted that about 60 percent of the injuries involving storm doors concerned the lower 3 age groups, i.e., children under 15 years of age, who account for only 28 percent of the general population. Children of this age typically run in and out of residences frequently, or at least, more often than adults. Since most storm doors are constructed with an upper and lower pane1, it may be reasonable to assume that most of the injury-causing breakages involve the lower panel which is more easily contacted by children due to their smaller height. Therefore, a substantial increase in safety may be expected if at least the lower annealed glass panel was replaced with safety glazing or even plywood, hardboard or equivalent product. The preferred retrofit would be to have safety glazing in the upper panel also. The likelihood of bodily contact with storm doors (which are usually spring loaded and many slam shut) suggests that the replacements for annealed glass just mentioned would be much more desirable from a safety standpoint than applying decals to annealed glass in these types of doors.

The following suggestions are applicable to storm doors:

(1) Replace annealed glass with safety glazing

(a) tempered glass

(b) acrylic plastic

(2) Correct any improper operation or installation of door

- sticking

- need for more than usual force to open or close

- slamming shut.

13 Bureau of Epidemiology, U.S. Consumer Product Safety Commission, Hazard Analysis, Injuries Involving Architectural Glass, November, 1974, p. 15. 
(3) Provide proper bedding for all glazing to avoid direct glass to metal contact.

(4) Replace at least the lower half of a door with plywood, hardboard or equivalent product.

(5) Provide a structurally supported plate to cover an area of glass on the door around the handle.

(6) Install metallic impact bars of grillwork over inside glass to at least shoulder height (95 percentile man). Installation to be hinged to permit easy cleaning of glass.

(7) Attach clear adhesive mylar to inside of glass.

3.2.4. Glass Pane1, Fixed (Window Wa11s)

A finding of the in-depth reports was that "while sliding glass door injuries usually occurred at home, those reported for fixed panels usually happened in public buildings such as hotels, stores, or office buildings."14

However, since window walls are present in residences the following suggestions may be useful to those individuals having such fixed glass panels.

(1) Replace all pitted, crazed or cracked glass panels with safety glazing.

(2) Install impact bars or latticework to a height of at least $46 \mathrm{~cm}$ (18 inches) from the floor on the inside. This installation should be 5 to $8 \mathrm{~cm}$ ( 2 to 3 inches) from the glass panel to permit access space for cleaning glass.

(3) Locate planters or furniture adjacent to fixed glass panels to make accidental contact with them impossible or unlikely.

(4) Drape heavy curtains next to window walls, for a measure or protection when curtains are drawn closed.

(5) Paint on plastic coatings or apply adhesive mylar.

(6) Apply decals at appropriate eye levels for children and adults.

\subsubsection{Glass Panels, S1iding (Patio Doors)}

Patio door injuries occurred most often when the injured person was unaware of the presence of the glass and ran or walked into the door. The injuries resulted in many severe lacerations generally to the lower leg, thigh or face. Examination of Table 2.1.4 indicates children and young adults under 25 received many more injuries than could be accounted for by population alone. The following suggestions provide for either replacement, improved annealed glass break characteristics, physical barriers or visual cues intended to reduce injury occurrence.

(1) Replace annealed slider with tempered glass.

(2) Correct any improper operation or installation of sliding glass panels.

14 Ibid., p. 30. 
(3) Apply decals at appropriate eye heights for children and adults.

(4) Create an optical imperfection such that it causes a ripple effect in glass when a person is moving, but not when standing still.

(5) Install resilient impact bars at about mid-height of the door.

(6) Paint on plastic coatings or apply adhesive mylar.

(7) Replace pitted, crazed or cracked glass with safety glass.

\subsubsection{Storm Windows}

The hazard patterns for storm windows were similar to prime windows except that additional patterns were found associated with installation or removal of the glass and with the storage of unmounted glass. The age groups most expected to handle various aspects of storm window maintenance, from ages 14 through 34, received higher accident ratios (Table 2.1.4) than other age groups. The following options for modification are applicable to storm windows:

(1) Replace all pitted, crazed or cracked storm windows with safety glazing.

(2) Correct any improper operation or installation of storm windows.

(3) Install proper bedding for all glass to avoid direct glass to metal contact.

(4) Paint on plastic coatings or apply adhesive mylar.

(5) Store windows in areas out of traffic pattern.

\subsubsection{Jalousie Glass Doors}

Very little information is available for injuries associated with jalousie glass doors. CPSC files included only two in-depth reports; one involved a non-glass injury and the other involved a cut caused by an edge of glass which slipped from metal clamps. The following suggestions, although not based upon any injury data, appear to be reasonable.

(1) Replace all pitted, crazed or cracked glass. with safety glazing.

(2) Cover inside of glass louvers with grillwork. This installation should be placed to allow operation of the louvers.

(3) Paint on plastic coatings.

(4) Correct any improper operation of door.

3.2.8. Jalousie Glass Windows

No in-depth information is available for jalousie glass windows. A possible problem, similar to jalousie doors, is the edge of glass which is exposed when the windows are opened. The following would possibly reduce injuries associated with the product.

(1) Replace all pitted, crazed or cracked glass with safety glazing.

(2) Locate planters or furniture adjacent to fixed jalousie glass windows to make accidental contact with them impossible or unlikely. 
(3) Drape heavy curtains next to jalousie glass windows for a measure of protection when curtains are drawn closed.

(4) For floor to ceiling windows, install impact bars and latticework to a height of at least $46 \mathrm{~cm}$ (18 inches) from the floor on the inside. This installation should be far enough out to permit operation of the louvers.

(5) Paint on plastic coatings.

3.2.9. Glass Doors, Not Otherwise Specified

Injury patterns reported for this category of data were similar to those reported for storm doors, e.g, lost balance--fell against door, pushed on glass, slammed door, etc. These doors were primarily exterior glass doors located in stores, schools, office buildings or homes.

The Bureau of Epidemiology has found that none of the glass door categories "adequately described doors (primarily exterior doors) that contain one or more small glass panels or doors that consist of a wood or metal panel in the lower half and a glass panel in the upper half."l 5 While Product Code 1805 is intended to include these doors, hospitals have not been consistent in coding injuries attributable to such products under category 1805. Therefore, surveillance data for these doors cannot be considered reliable.

Although many of these doors are not located in the home, modifications which follow are intended to provide for safer exterior doors in homes.

(1) Replace glass with plywood, hardboard or equivalent product (if visibility through door is not necessary).

(2) Replace all cracked, broken or pitted panes with safety glass (laminated; tempered; plastic).

(3) If glass is near a handle or push plate replace glass with safety glass. (Making less harmful if broken.)

(4) Hang clear plastic vinyl (.010") over glass on outside and batten down edge with wooden strips; hang cloth or place tie curtains over glass on inside, attached top and bottom. (Vinyl can also be battened on both sides.)

(5) Cover glass with grillwork on both sides using wood, masonite, metal or wire mesh. Openings in grillwork should not be large enough to put a fist or hand through. Installation should be hinged or easily removable for clearing glass.

(6) Attach clear adhesive mylar to inside of glass.

(7) Paint plastic coating onto glass.

(8) Correct improper installation of the door if it sticks or if slamming of door is necessary to close it; or install checking device if door normally slams shut.

${ }^{15}$ Ibid., pp. 6-7. 


\section{BENEFIT-COST MODEL}

The purpose of calculating a benefit-cost ratio for the retrofit modifications is to determine whether proposed costs can be justified considering present medical costs and other calculable costs for annealed glass products. The model assumes, for analysis purposes only, that retrofits are accomplished immediately, and therefore all projected injuries which would have occurred are avoided. The results obtained apply to the average product being modified; that is, an implicit assumption is made that all installations have an equal probability of being involved in an injury causing accident. ${ }^{16}$

A benefit-cost approach considers the costs of making modifications to annealed glass products, and the benefits expected (the return expected by virtue of injuries avoided because of the modification). In order to obtain such information it is necessary to examine the circumstances or patterns of injuries, and to discover which modifications would be effective in reducing injuries. The cost of such modifications must also be estimated. A benefit-cost model for modification of existing architectural glass products (annealed) follows:

\subsection{Benefit of Averted Medical Injury Costs}

Consider a modification which essentially elminates all injuries attributable to a product. ${ }^{17}$ The injuries averted would equal a projection of injuries expected over the entire life of the product.

The life of glass products is influenced by two major factors:

(1) Breakage - which may or may not cause injury, and

(2) House obsolescence - the house is either destroyed or renovated resulting in replacement of the product.

${ }^{16}$ The data indicate that products used by high risk segments of the population (i.e., children) appear to be involved in a greater proportion of injuries. Therefore, when interpreting the results, families with children should consider making changes for lower benefit-cost ratios that households solely composed of adults.

${ }^{17}$ It is recognized that annealed glass is not the sole contributing factor in injuries for these products, and therefore the accuracy of this assumption depends upon the fraction of injuries attributable to other product characteristics .

Additionally, the assumption that retrofits are 100 percent effective can not be valid and so modifications would not eliminate all injuries. The assumption permits an analysis which results in an overestimation of benefits, therefore low benefit-cost ratios resulting from analyses using this assumption are beyond consideration. 
The following equation (derivation given in Appendix B) was applied:

$$
\hat{\mathrm{p}}_{\mathrm{n}}=\mathrm{p}_{\mathrm{o}}(1+\mathrm{r} \lambda-\mathrm{r}-\lambda)^{\mathrm{n}}
$$

where $\hat{\mathrm{P}}_{\mathrm{n}}$ is the number of architectural glass products remaining in year $\mathrm{n}$ after breakage and removal of obsolete housing,

and where $\mathrm{P}_{\mathrm{O}}=$ number of products at the start,

$r=$ annual rate of product breakage, and

$\lambda=$ annual rate of removal of obsolete housing.

From this equation it is possible to predict the products remaining in any year, once estimates are obtained for the initial number of products, the rate of product breakage and the rate of housing obsolescence. The total number of product related injuries over time can be estimated using the above equation and assuming a proportional decrease in injuries as potentially hazardous products are removed or replaced.

The conversion of the number of injuries in any year to a monetary value for medical costs can be accomplished based on an average medical cost value per injury. Since these injuries may be occurring in any year after the starting point of the analysis, the monetary value of medical costs must be discounted ${ }^{18}$ in order to compare these values with the costs of retrofits. The net sum of avoided injury costs over the life time of products approximates the benefit derived from modifying products at the initiation of the analysis to prevent future injuries. The sum represents avoided injury medical costs attributable to the expenditures made to make products safer. The benefits can be divided by the total products at the start $\left(\mathrm{P}_{0}\right)$ to yield the benefits expected per product.

\subsection{Cost Derivation for Retrofits}

The cost side of the equation is derived from knowledge of the number of products containing annealed glass and the approximate costs required to modify each product. It was assumed, for compatibility with benefit assumptions, that the entire population of products was modified, and therefore future injuries due to annealed glass were totally avoided. The cost equation is represented by:

$$
\mathrm{TC}=\mathrm{P}_{\mathrm{O}} \mathrm{CM}
$$

where $\mathrm{TC}=$ total costs for product modification, $\mathrm{P}_{\mathrm{o}}=$ number of products at the start, and $\mathrm{CM}=$ average modification cost per product .

${ }^{18}$ Discount rates are intended to permit the evaluation of alternative investments with expenditures occurring at different points in time and reflect the long term borrowing rate of investment capital. 
The average modification costs of the retrofit options suggested in Section 4.1 depend upon many variables, among which are the price of necessary materials (e.g., tempered glass) and whether the services of professionals are required to make the modifications. Because of price differentials between retail establishments and the uncertainty associated with who will perform the retrofit, it is not possible to associate a firm cost to the retrofits. A rough estimate was obtained by sampling a few retail establishments and ascertaining their charges for materials and services associated with the proposed retrofits. These cost estimates are shown in Table 4.2 .

\subsection{Computation of Benefits for Retrofits}

Table 4.3.1 provides the data required to calculate the benefits of retrofit (the potentially averted injury medical costs). Estimates for breakage rates for the various products as well as estimated average medical costs came from the Consumer Safety Glazing Committee Economic and Environmental Subcommittee's Final Report, February 7, 1975.19

The averted injury costs computation used a 10 percent discount rate and an assumed annual housing obsolescence rate of 1.0 percent. 20,21 Computations were carried out for a 50 year period. 22 The benefit computations assume that injury costs are based solely on the total estimated hospital emergency visits and applies the average medical cost of treatment. Table 4.3 .2 presents the results and permits consideration of the expenditures per product for retrofits which are benefit-cost defensible based upon averted medical costs.

Since the computation only considers medical costs of emergency room cases, it does not include injuries treated elsewhere, an allowance for pain and suffering, nor did it include lost time from work. Also excluded from the computation are benefits derived from saving lives or preventing permanent physical impairments and associated retraining costs. The computation does not attempt to project any changes in medical costs. The averted injury medical costs in Table 4.3.2 are for an average product modification without consideration of the household members.

${ }^{19}$ The committee derived its medical cost estimates from A Procedure for Estimating the Costs of injuries Associated with Household Products. J. Wulff, National Commission on Product Safety, March 1970, and updated the medical costs to October 1974 using the Consumer Price Index for Urban Wage Earners and Clerical Workers, Medical Care - Series F.

${ }^{20}$ The discount rate of 10 percent was chosen to conform to Office of Management and Budget Circular No. A-94, March 1972.

${ }^{21}$ The Economic and Environmental Subcommittee used both a 1.0 percent and a 0.6 percent rate of obsolete housing. The 1.0 percent rate assumption agrees with the fraction of the total housing units removed from the inventory from 1960 to 1970, according to the U.S. Census of Housing: 1970, Components of Inventory Change, Final Report HC(4)-1, 1973.

22By the 50 th year using a 10 percent discount rate only 0.23 percent of the medical costs being incurred would be added to benefit totals, therefore, the analysis was terminated at this point. 


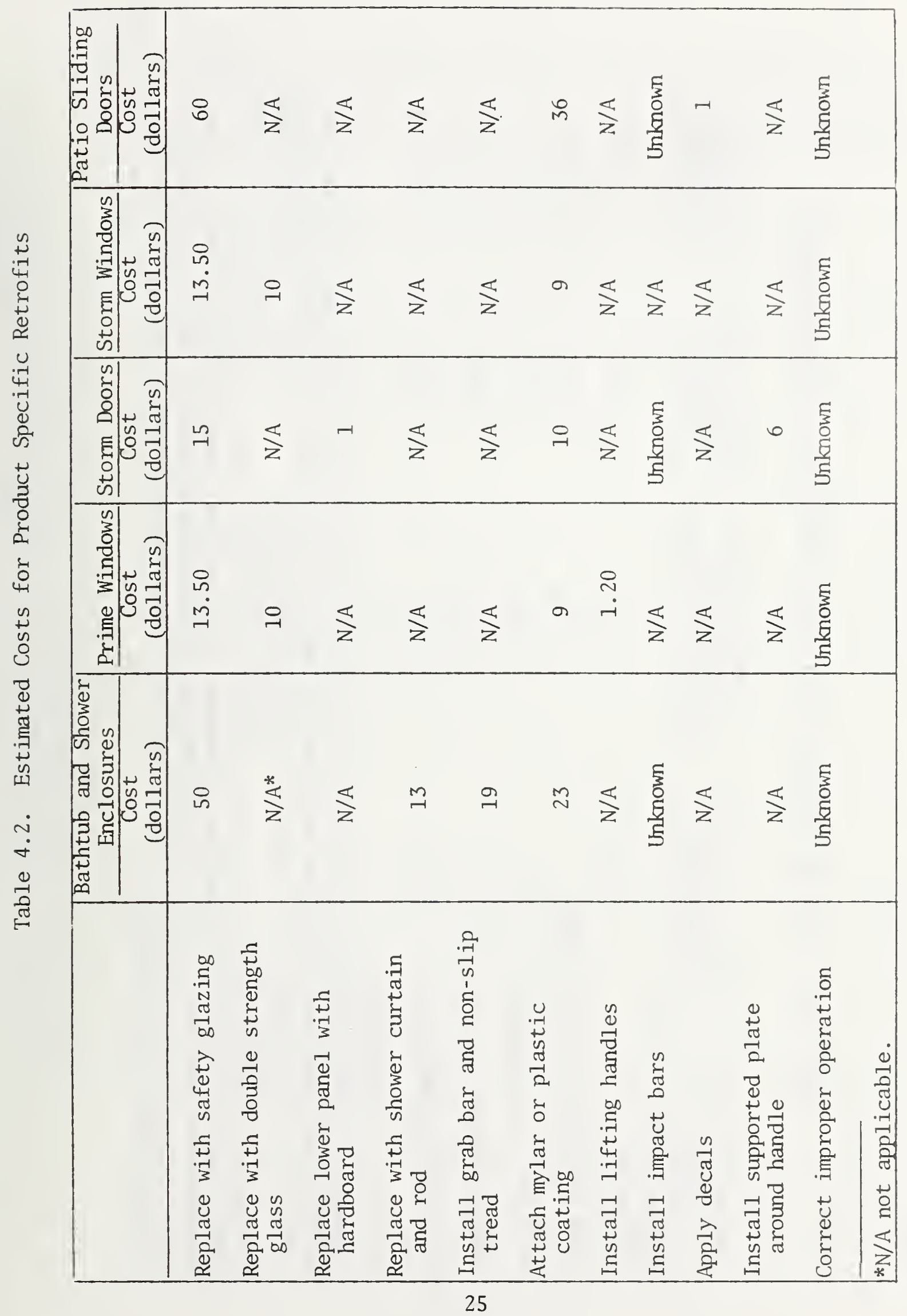




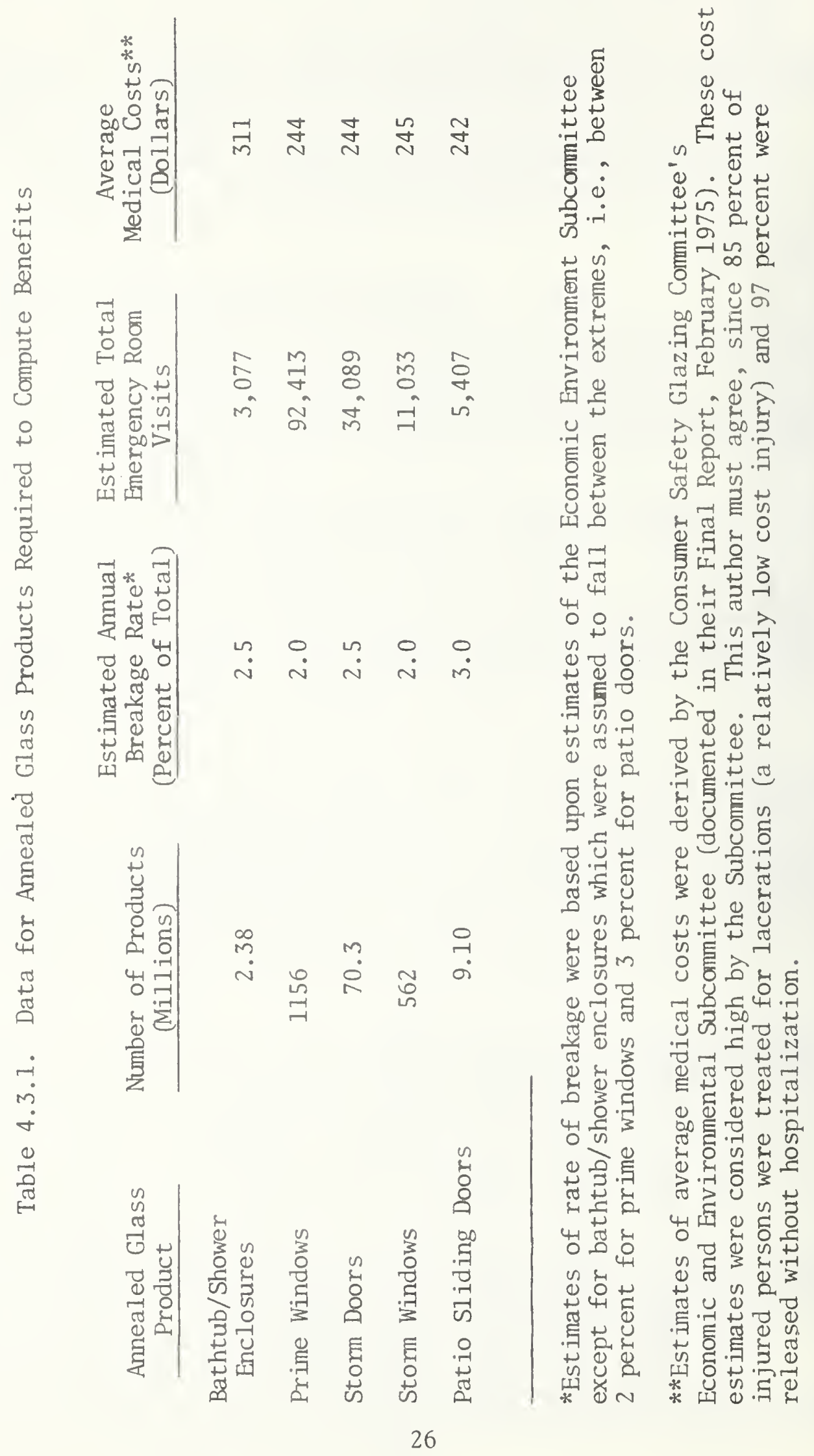




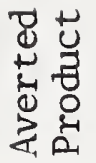

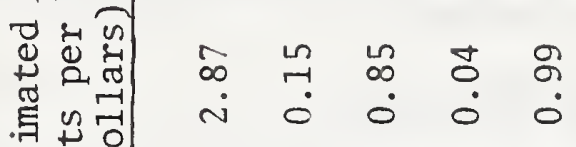

$$
\begin{aligned}
& \text { 势设 }
\end{aligned}
$$

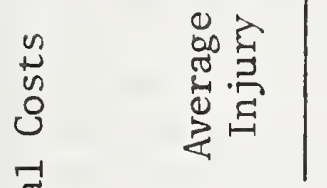

$$
\begin{aligned}
& \text { 倠 } \\
& \text { 己 }
\end{aligned}
$$

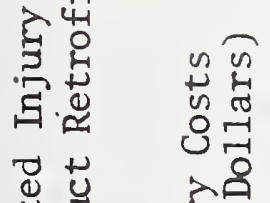

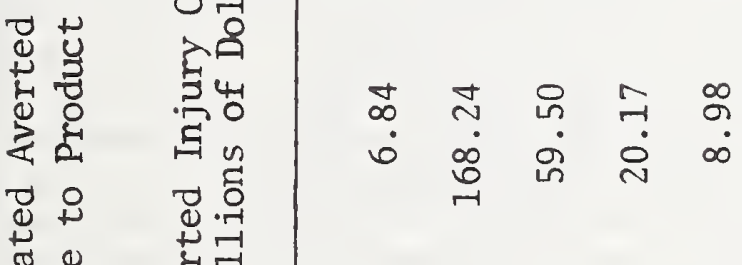

$$
\begin{aligned}
& \text { 垫点 } \\
& \text { ن } \\
& m< \\
& \dot{\forall} \\
& \text { त्र }
\end{aligned}
$$

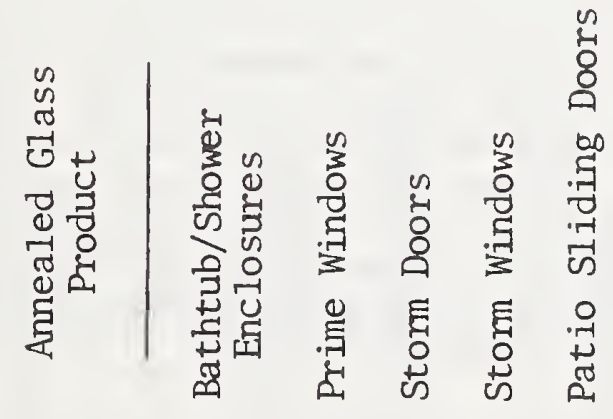


The benefit calculation for each of the products under study assumed, for the purpose of analysis, that the retrofits were 100 percent effective in preventing injuries. As a retrofit's effectiveness is lowered the benefit also is lowered. To the extent that additional behavioral and engineering knowledge becomes available regarding effectiveness, the benefit should be adjusted accordingly.

\subsection{Analysis of Benefit-Cost Derivation}

The benefit-cost ratio derived from the previous equations is equal to the benefit (the discounted sum of expected injury medical costs) divided by the total cost for product modification (TC). The equations can be modified to include additional information once available, such as the fraction of injuries actually attributable to annealed glass or the number of deaths. The benefit-cost values derived can be used to indicate if any of the proposed retrofits are within a reasonable range for implementation consideration.

The benefit-cost ratios in Table 4.4 .1 yield only two retrofit options with ratios meeting or approaching 1.0. Generally a ratio of benefits to costs of 1.0 is the lower bound of acceptable values for decisions. Therefore, those retrofit costs per product greatly exceeding the benefits per product values must be justified on other grounds. If the conventional benefit-cost decision point of 1.0 is selected to evaluate the results of Table 4.4.1 only one of the product specific retrofit approaches met the decision criterion. This retrofit is the application of decals to patio sliding galss doors, which is at the point of indifference (benefit-cost very close to 1.0). Therefore, for a household which considers itself as having a higher risk than average, the application of decals would be warranted. The replacement of the lower panel of storm doors with hardboard might also be considered by high risk households, since its benefitcost ratio is 0.85 .

The computations, however, include only those estimated benefits based on potentially avoided injuries treated in hospital emergency rooms. The magnitude of additional benefits relating to injuries not treated in emergency rooms, allowances for "pain and suffering," avoided lost time from work, saving lives or preventing permanent physical impairments and associated retraining costs are not easily calculable. Additional analysis may be performed to indicate what magnitude of benefits these other factors would have to contribute to achieve the conventional benefit-cost decision criterion of 1.0. Table 4.4.2 indicates that only one more retrofit option approaches acceptability even after quadrunling the benefit values. This retrofit, for bathtub and shower enclosures, involves replacement of the annealed glass enclosure with a rod and curtain.

For the last retrofit approach in Table 4.4.1, correct improper operation of the products, costs could not be estimated. Corrective maintenance, however, not only is important for safety reasons but can also be supported on functional grounds. The recommendations that storm windows and storm door glass not in use be stored out of traffic patterns and that broken glass be appropriately disposed of are not easily quantified for 


\begin{tabular}{|c|c|c|c|c|c|c|c|c|c|c|c|c|}
\hline 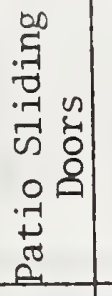 & กิ. & $\underset{z}{z}$ & $1 \ll$ & $\overleftarrow{z}$ & $\frac{\nwarrow}{z}$ & $\stackrel{m}{o}$ & $\aleph_{z}$ & $\begin{array}{l}E \\
\xi \\
E \\
E \\
E\end{array}$ & ஜே & $\frac{4}{z}$ & $\begin{array}{l}\text { E } \\
\text { 总 } \\
\text { 点 }\end{array}$ & \\
\hline 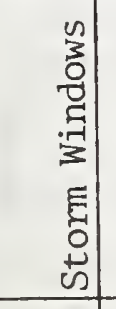 & $\stackrel{\text { m. }}{0}$ & ठ & $\underset{\zeta}{z}$ & $\lesssim$ & $\frac{\nwarrow}{z}$ & \&. & $\overleftarrow{z}$ & 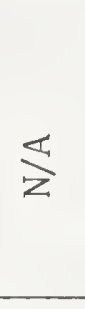 & 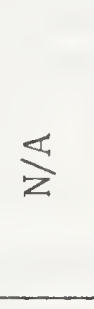 & $\frac{\nwarrow}{z}$ & 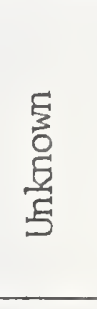 & \\
\hline $\begin{array}{c}n \\
0 \\
0 \\
0 \\
E \\
0 \\
\omega \\
\omega\end{array}$ & 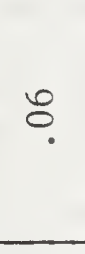 & 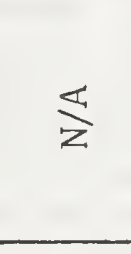 & $\begin{array}{l}\stackrel{\infty}{\infty} \\
\infty \\
0\end{array}$ & 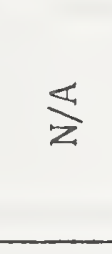 & 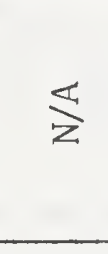 & $\stackrel{\infty}{0}$ & $\overleftarrow{z}$ & 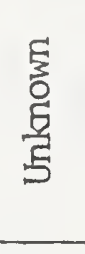 & $\frac{\nwarrow}{z}$ & $\stackrel{+}{\sim}$ & 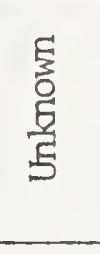 & \\
\hline 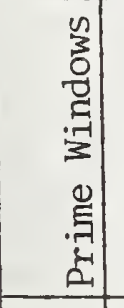 & పे & ర్ర. & $\overleftarrow{\zeta}$ & $\lesssim$ & 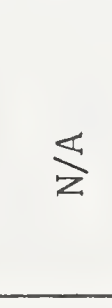 & ऽ̊. & $\stackrel{ }{?}$ & $\underset{\zeta}{\grave{z}}$ & $\lesssim$ & $\frac{\nwarrow}{z}$ & 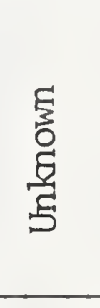 & \\
\hline 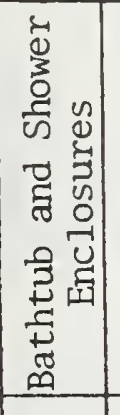 & $\stackrel{0}{0}$ & $\sum_{z}^{*}$ & $\overleftarrow{z}$ & $\stackrel{\sim}{\sim}$ & $\stackrel{n}{\longrightarrow}$ & $\stackrel{\sim}{\neg}$ & $\ll$ & 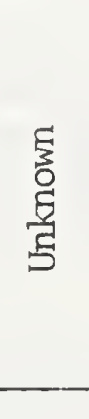 & $\frac{\nwarrow}{z}$ & 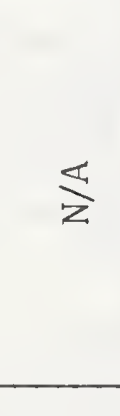 & $\begin{array}{l}\xi \\
\text { క్ } \\
\Xi \\
\text { है }\end{array}$ & \\
\hline & 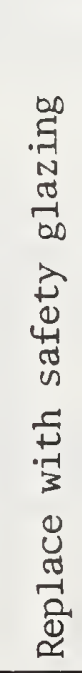 & 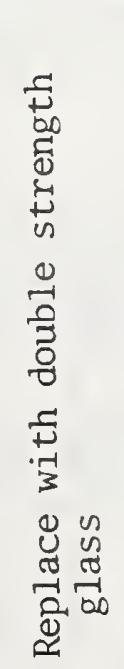 & 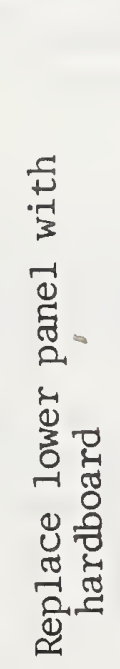 & 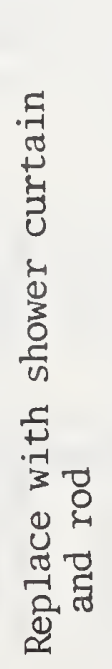 & 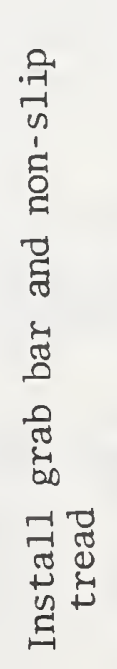 & 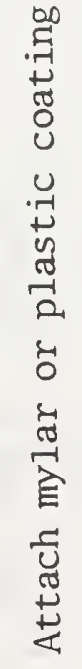 & 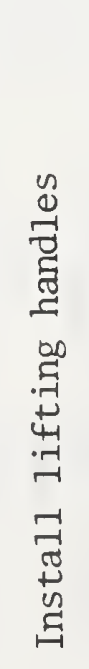 & 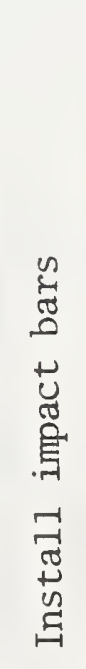 & 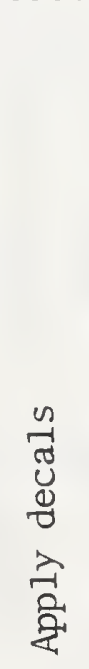 & 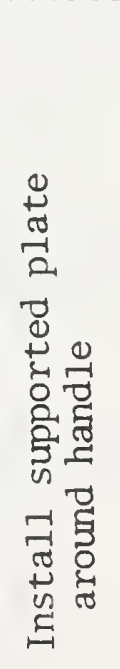 & 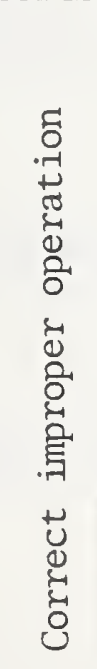 & 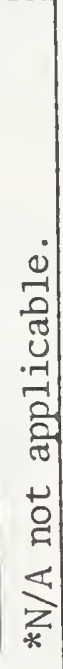 \\
\hline
\end{tabular}




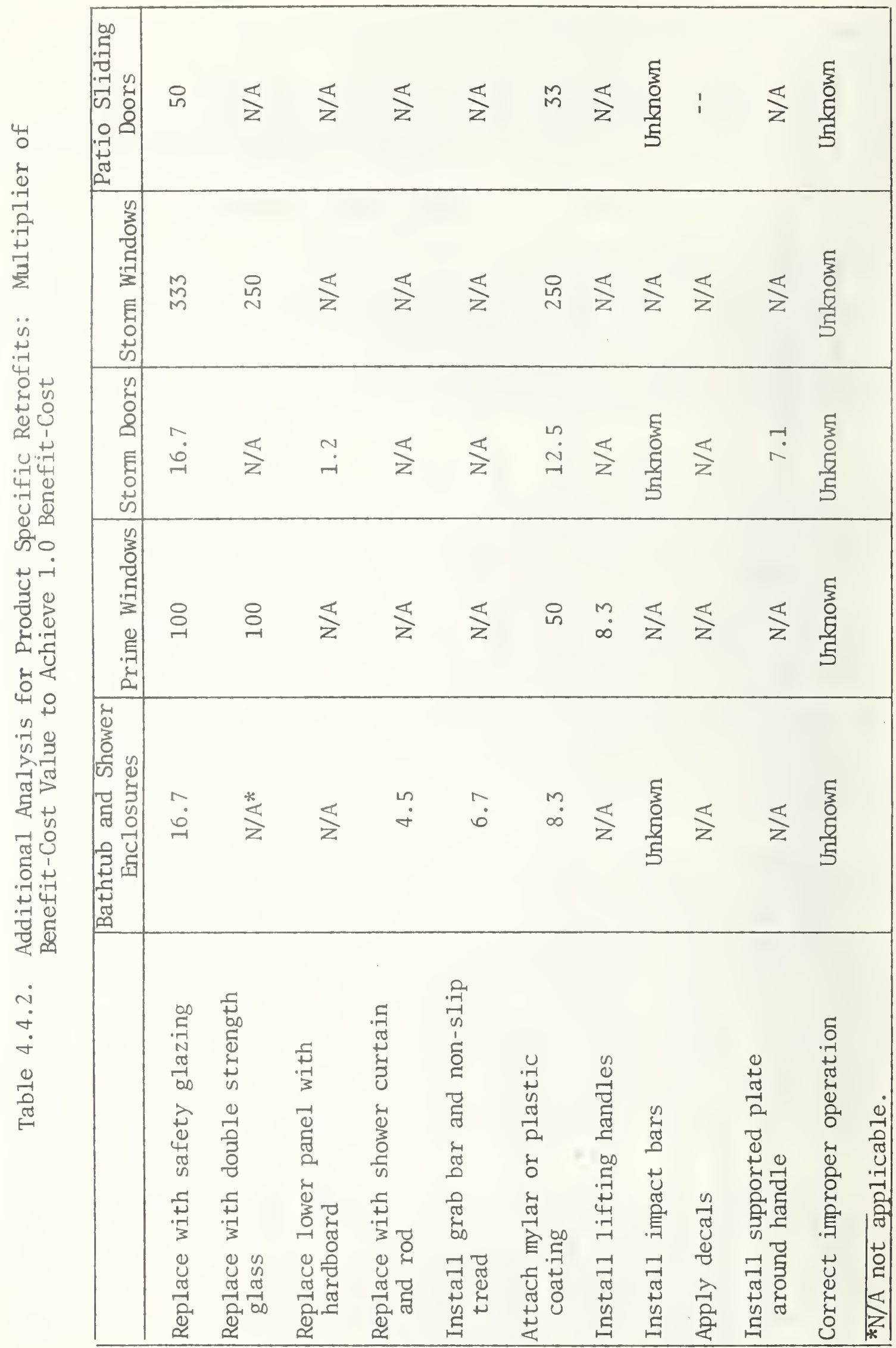


benefit-cost calculations. Costs for proper storage and disposal would depend upon individual's utility values. These computations were not attempted. Costs estimates were not included for impact bars which could be used on bathtub enclosures, storm and patio doors, since standard hardware was not found to be available.

For prime windows and storm windows the benefit-cost computations indicate that the only actions appropriate are keeping them in good working order, properly disposing of broken glass and storing unused panels out of the way.

\subsection{Approaches for Encouraging Architectural Glass Safety}

One of the objectives of this project was to recommend feasible approaches to implement the most promising retrofit options. The project tasks were divided into two phases, which were carried out simultaneously, the benefit-cost analysis and the development of approaches suitable for encouraging safety modifications to architectural glass products in residences. The study has resulted in a set of alternatives (Appendix C) which are generally applicable to the implementation of safety oriented modifications for products existing in the home. These approaches were developed without the results from the benefit-cost analysis (due to the parallel timing of these tasks) so they were subsequently reexamined. Their applicability was reviewed with respect to the two modification options suggested for patio sliding glass doors and storm doors, as well as to the concepts of correcting improper product operation and storing glass panels out of traffic.

A set of potential implementation approaches was selected which could apply to improving the safety of architectural glass products now in place in residences. ${ }^{23}$ Review of these approaches, in view of the findings of the benefit-cost analyses, led to the conclusion that it would be appropriate for CPSC to undertake an informational and educational approach. 24

An informational campaign would bring to the public's attention the hazards associated with patio glass doors and storm doors. A fact to be emphasized during any such campaign is, that for both of these products, children are subjected to many more injuries than can be accounted for

${ }^{23}$ The implementation approaches were selected from the set of countermeasures developed during the first phase of this project and documented in NBSIR 75-651, Procedural Options to Reduce the Risk of Injury from Products Installed in Residences, June 1975.

${ }^{24} \mathrm{No}$ attempt has been made to develop an analysis of the cost associated with information and education campaigns by the CPSC or their effectiveness for implementation purposes. 
by population alone. Such emphasis would bring the problem to the attention of parents and alert them to the possibility that, although they "respect" these products, their children may not have knowledge of product hazards. An education effort must recognize that the problem involves alerting children and adults to the proper approach for using architectural glass products. Adults must be influenced to make the necessary safety modifications, and they must be given adequate information with which to make products safer. In addition to efforts designed to educate the general public, some effort is warranted to educate the editors of interior design and home decoration oriented magazines. Articles illustrating attractive decoration of patio sliders with decals could contribute toward consumer acceptance of this idea.

\section{CONCLUSIONS}

The analyses indicated that the only economically justifiable options are the application of decals to patio sliding glass doors and possibly the replacement of annealed glass in the lower panel of storm doors with hardboard for households with higher than average risk. Further, it is unlikely that the introduction of factors not included in the analyses would increase benefits sufficiently to justify consideration of additional options, since even quadrupling the calculated benefits would fail to produce a favorable benefit-cost ratio.

Informational and educational campaings by the CPSC were found the most appropriate of the implementation approaches reviewed. The potential implementation approaches were considered for their applicability to the modification options suggested for patio sliding glass doors and storm doors and to the correction of improper product operation and the storage of glass panels out of traffic. The Commission should consider a dual approach to implement safety modifications through both information dissemination and educational activities. The purpose of the informational campaing would be to bring the hazards associated with architectural glass products to the public's attention. A factor to be enphasized is the extent to which these accidents involve children. An educational effort would involve: alerting children and adults to the proper methods for using and storing architectural glass products, influencing adults to take actions to make products safer, and providing information which enables concerned individuals to make products safer. 
APPENDIX A.

Derivation of Population Estimates for

Annealed Glass Products

The source of information providing the basis for determination of the product populations was the Final Report of the Architectural Glass Project's Consumer Safety Glazing Committee's Economic and Environmental Subcommittee submitted to the CPSC in February, 1975. The subcommittee compiled statistics and estimates from the U.S. Census Bureau's Structural Characteristics of Housing and surveys performed for the National Association of Home Builders, the Architectural Aluminum Manufacturers Association, the Aluminum Extrusion Council, the National Woodwork Manufacturers Association and the Consumer Safety Glazing Committee.

A.1. Bathtub Enclosures and Shower Doors

Basis for determination:

Total annealed glass used in bathtubs and showers $=3.62$ million $\mathrm{m}^{2}$ (39 million $\mathrm{ft}^{2}$ )

Average area of glass panels $=1.22 \mathrm{~m}^{2}\left(13.1 \mathrm{ft}^{2}\right)$

Average panels per enclosure unit $=1.25$

Analysis:

Number of pane $1 \mathrm{~s}=\frac{3.62 \text { million } \mathrm{m}^{2}}{1.22 \mathrm{~m}^{2} / \text { pane } 1}=2.98$ million

Number of units $=\frac{2.98 \text { million panels }}{1.25 \text { panels } / \text { unit }}=2.38$ million

A.2. Prime Windows

Basis for determination:

Total glazed area $=966,696,110 \mathrm{~m}^{2}\left(10,405,430,000 \mathrm{ft}^{2}\right)$

Single glazed $\quad=878,269,140 \mathrm{~m}^{2}\left({ }^{\prime} 9,453,610,000 \mathrm{ft}^{2}\right)$

Double glazed $\quad=88,426,974 \mathrm{~m}^{2}\left(951,820,000 \mathrm{ft}^{2}\right)$

Total occupied housing units $(1975)=73,548,000$

Analysis:

Assuming average window $=0.836 \mathrm{~m}^{2}\left(9 \mathrm{ft}^{2}\right)$

Total windows $=\frac{966,696,110 \mathrm{~m}^{2}}{.836 \mathrm{~m}^{2} \text { per window }}=1156$ million 
A.3. Storm Doors

Basis for determination:

1 and 2 family units

1 and 2 family units in $1970=52,235,000$ units

2 doors per unit suited to storm doors

66 percent of doors installed prior to 1970 have storm doors

18 percent of new construction install storm doors

Cumulative total of U.S. population requiring safety glazing

by year 1970 to 1975 - see Table 2.1

New housing starts in $1971=1,217,000 ; 1972=1,383,000$;

$1973=1,191,000 ; 1974=700,000$.

\section{Apartments}

Apartment units in $1970=13,392,000$

Doors per unit suited to storm doors $=1$

33 percent of doors suited have storm doors

New apartment units in $1971=868,000 ; 1972=995,000$;

$1972=867,000 ; 1974=700,000$.

Analysis of Storm Doors Containing Annealed Glass

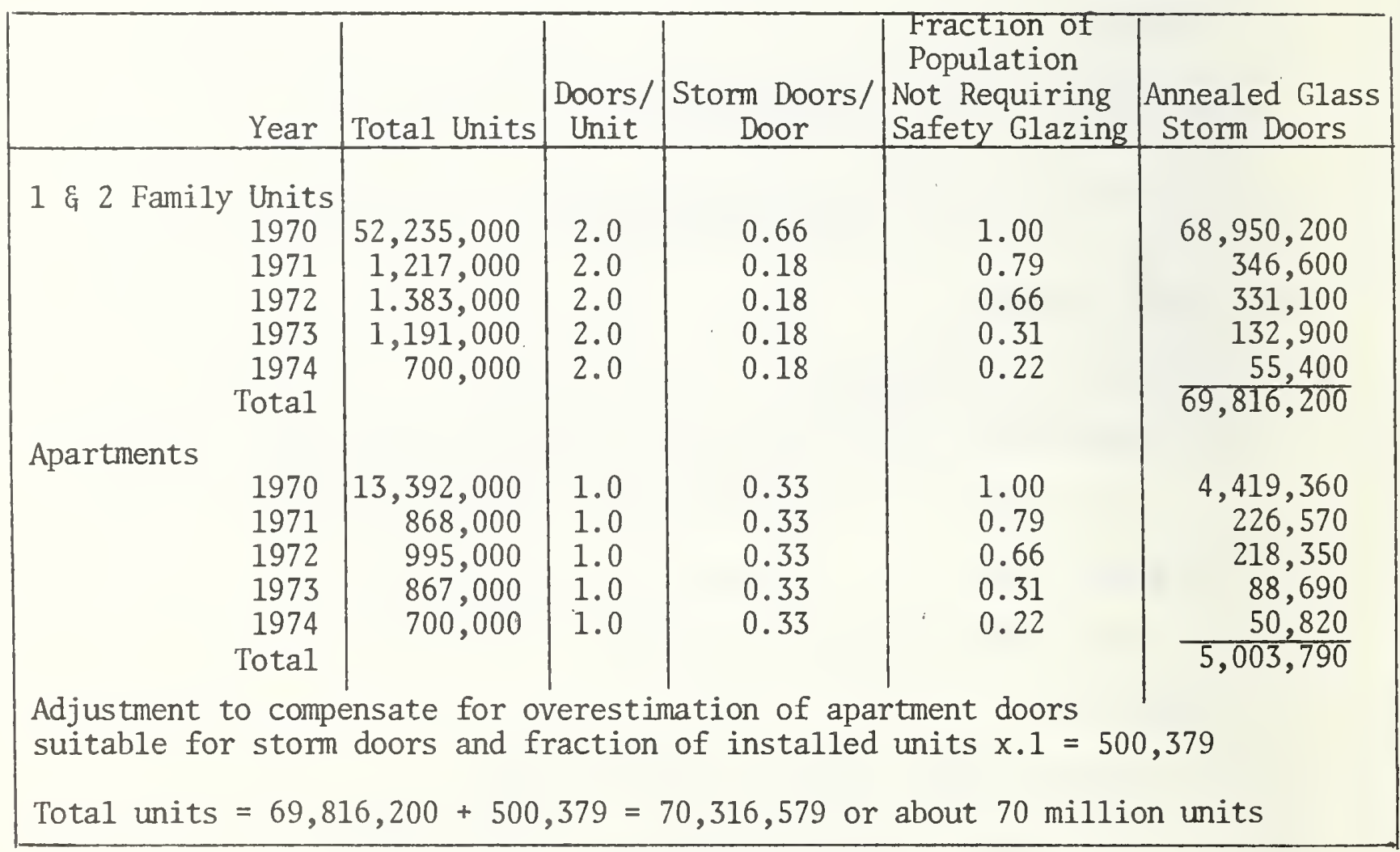




\section{A.4. Storm Windows}

Basis for determination:

Single strength glass in use $=469,801,400 \mathrm{~m}^{2}\left(5,056,900,000 \mathrm{ft}^{2}\right)$ Analysis:

$$
\begin{aligned}
& \text { Assuming average window area }=0.836 \mathrm{~m}^{2}\left(9 \mathrm{ft}^{2}\right) \\
& \text { Total storm windows }=\frac{469,801,400 \mathrm{~m}^{2}}{0.836 \mathrm{~m}^{2} \text { per window }}=562 \mathrm{million}
\end{aligned}
$$

\section{A.5. Patio Sliding Doors}

Basis for determination:

Total patio doors in existence

Total panels

$28,800,000$

Glazing area $57,793,125 \mathrm{~m}^{2}\left(622,080,000 \mathrm{ft}^{2}\right)$

Estimated annealed glazing area $39,732,973 \mathrm{~m}^{2}\left(427,680,000 \mathrm{ft}^{2}\right)$

Estimated tempered glazing area $17,874,545 \mathrm{~m}^{2}\left(192,400,000 \mathrm{ft}^{2}\right)$

Estimated annealed replaced with tempered $(8 \%)$

$$
\begin{array}{r}
3,178,585 \mathrm{~m}^{2}\left(34,214,000 \mathrm{ft}^{2}\right) \\
36,554,151 \mathrm{~m}^{2}\left(393,465,600 \mathrm{ft}^{2}\right) \\
21,053,167 \mathrm{~m}^{2} \quad\left(226,614,400 \mathrm{ft}^{2}\right)
\end{array}
$$

Total existing annealed

Total existing tempered Analysis:

Average area of patio door $=\frac{57,793,125 \mathrm{~m}^{2}}{14,400,000 \text { patio doors }}=4.01 \mathrm{~m}^{2}$

Accounts for 2 panels per door plus a fraction which are double glazed.

$\begin{aligned} \text { Number of annealed doors } & =\frac{36,554,151 \mathrm{~m}^{2}}{4.01 \mathrm{~m}^{2} / \text { patio door }} \\ & =9 \text { million door systems }\end{aligned}$ 
A.6. Entrance and Exit Doors with Glass

Basis for determination:

Total glazing material in use in residential doors $=21,422,391 \mathrm{~m}^{2}$ $\left(230,803,970 \mathrm{ft}^{2}\right)$

Mean value of glazing area all doors with glass $=0.279 \mathrm{~m}^{2}$ $\left(3 \mathrm{ft}^{2}\right) /$ door

Analysis:

Number of residential doors with glass $=\frac{21,442,391 \mathrm{~m}^{2}}{0.279 \mathrm{~m}^{2} / \text { door }}$

$$
=77 \text { million doors }
$$

\section{A.7. Sidelites}

Basis for determination:

One door in 45 is installed in a door frame with sidelites. Analysis:

Residential units with sidelites $=\frac{77 \text { million doors }}{45 \text { doors } / \text { sidelite }}=1.7$ million 
APPENDIX B.

Derivation of the Benefit Equation and

Computation of Averted Injury Medical Costs

\section{B.1. Derivation of the Benefit Equation}

The net present value of medical injury costs averted by retrofit of hazardous products can be calculated by prediction of the injuries, which would have occurred over the life of the product without the retrofit, and application of the associated medical cost for each injury. The net present value computation discounts medical costs occurring in the future and sums these costs over a fifty year period. The discount factor permits the comparison of two alternatives: (1) doing nothing, in which case injuries are expected to occur and accumulate medical costs over the life of the product; and (2) retrofitting the product to make it safe, thus avoiding all future injuries but immediately incurring the cost of retrofit.

The net present value of medical injury costs may be represented by the algebraic equation

$$
\mathrm{NPV}=\sum_{\mathrm{n}=1}^{50} \hat{\mathrm{P}}_{\mathrm{n}} \text { AI AMC } \mathrm{d}_{\mathrm{n}}
$$

where NPV is the net present value of medical injury costs, $\hat{P}_{n}$ is the number of products remaining in year $n$, AI is the average annual injury rate per product, AMC is the average medical cost per injury, and $d_{n}$ is the discount factor in year $n .^{*}$

The derivation of $\hat{\mathrm{P}}_{\mathrm{n}}$, the number of products remaining in year $n$, depends upon several parameters which will be introduced and defined. The products remaining at the end of any year depend upon the number of products in the beginning of the year, the number of products which are broken (replaced with safety glazing), as well as those products which are eliminated during the year when housing is removed from the inventory. The products remaining after breakage the first year can be expressed as

$$
\mathrm{P}_{1}=\mathrm{P}_{0}(1-\mathrm{r})
$$

where $P_{0}$ is the total products initially and $r$ is the annual rate of removal of products due to breakage.** The removal of products resulting from housing inventory reduction may be represented by

$$
\hat{\mathrm{P}}_{1}=\mathrm{P}_{1}(1-\lambda)
$$

*The computation of NPV of medical injury costs were summed over a fifty year period. Although, because of discounting, approximately 96 percent of the costs were incurred by the 25 th year.

**The annual rate of removal of products due to breakage ( $\mathrm{r}$ ) has been treated as a constant over time, although glass is known to become gradually weaker with age. This is not expected to introduce a significant error, since the value of $r$ is only an approximation. 
where $\lambda$ is the annual rate of removal of products due to house obsolescence* Using equation (2) in equation (3) yields

$$
\hat{\mathrm{P}}_{1}=\mathrm{P}_{0}(1-\mathrm{r})(1-\lambda) \text {. }
$$

Continuing to the end of the second year the products remaining after breakage can be expresses as

$$
\mathrm{P}_{2}=\hat{\mathrm{P}}_{1}(1-\mathrm{r})
$$

and after removal of products for house obsolescence

$$
\hat{\mathrm{P}}_{2}=\hat{\mathrm{P}}_{1}(1-r)(1-\lambda) \text {. }
$$

Using equation (4) in equation (6) yields

$$
\hat{\mathrm{P}}_{2}=\mathrm{P}_{0}(1-\mathrm{r})(1-\lambda)(1-\mathrm{r})(1-\lambda)
$$

or equation (7) may be rewritten as

$$
\hat{\mathrm{P}}_{2}=\mathrm{P}_{0}(1-r)^{2}(1-\lambda)^{2} \text {. }
$$

During the third year products remaining after breakage and removal due to house decay may be expressed as

$$
\hat{\mathrm{P}}_{3}=\hat{\mathrm{P}}_{2}(1-\mathrm{r})(1-\lambda)
$$

and using equation (8) in equation 9 yields

$$
\hat{\mathrm{P}}_{3}=\mathrm{P}_{0}(1-r)^{3}(1-\lambda)^{3} \text {. }
$$

The general form, therefore, is

$$
\hat{\mathrm{P}}_{\mathrm{n}}=\mathrm{P}_{0}(1-r)^{\mathrm{n}}(1-\lambda)^{\mathrm{n}}
$$

or equation (11) may be rewritten as

$$
\hat{\mathrm{P}}_{\mathrm{n}}=\mathrm{P}_{0}(1+r \lambda-r-\lambda)^{\mathrm{n}} \text {. }
$$

Using equation (12) in equation (1) yields

$$
\mathrm{NPV}=\sum_{n=1}^{50} P_{0}(1+r \lambda-r-\lambda)^{n} \text { AI AMC } d_{n}
$$

and removing the constant terms from the summation

$$
\mathrm{NPV}=\mathrm{P}_{0} \text { AI AMC } \sum_{n=1}^{50}(1+r \lambda-r-\lambda)^{\mathrm{n}} \mathrm{d}_{\mathrm{n}} .
$$

*It is recognized the unlike glass, which has a constant rate of breakage over time, houses probability of being removed from the inventory is not constant and increases substantially after many years of existence. However, rather than classify housing by differential removal rates, an average rate of removal was selected for simplicity of analysis from U.S. Census data over a ten year period. 
The product $\mathrm{P}_{0} \mathrm{AI}$, (the initial product times the annual injury rate per product) equals the annual number of accidents occurring with the initial population of products. This value may now be set equal to either the annual number of injuries treated in emergency rooms based upon NEISS estimates, or the total projected cases in the U.S. per year.

\section{B.2. Computation of Benefits}

Table 4.3.1 provides data for annealed glass architectural products required to calculate benefits using equation (14). In addition, the computations for all products used a housing obsolescence rate $(\lambda)$ of 0.01 and a discount rate (d) of 10 percent. The discount factor $\left(d_{n}\right)$ can be derived from the discount rate $(d)$.

$$
d_{n}=\frac{1}{(1+d)^{n}}
$$

Table $B$ presents the results of the benefit computation for bathtub and shower enclosures, prime and storm windows, storm doors and patio sliding doors. 


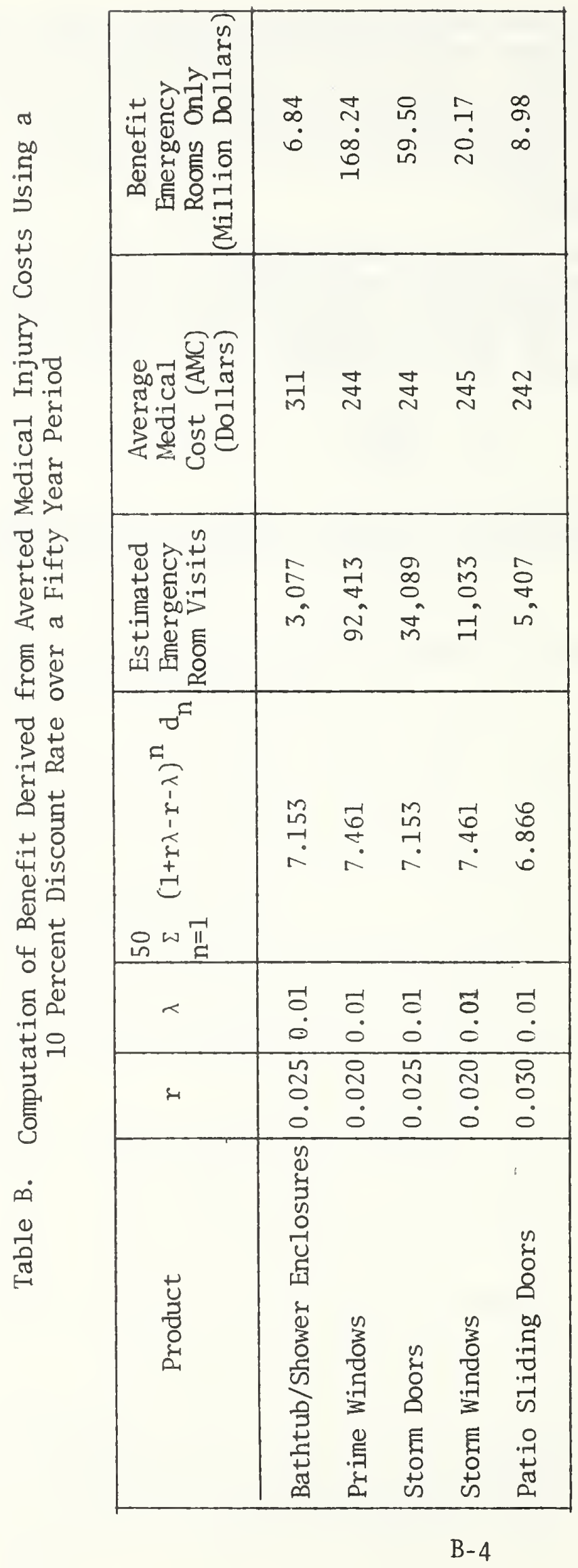


APPENDIX C.

Implementation Approaches for Encouraging Safety Modification of Hazardous Architectural Glass Products

This appendix will discuss implementation approaches which are appropriate to consider for encouraging the safety modification of component parts of residences. Although the implementation approaches are generally applicable to component parts of residences, the discussion which follows is structured for application to architectural glass products. It is intended that the implementation approaches, as discussed in this appendix, be viewed as a spectrum of options available to the Commission. The selection of an implementation approach or set of approaches to be applied would depend upon the results of additional analyses for specific products, which would consider factors such as retrofit effectiveness and benefit-cost.

The first phase of work on this project identified, for products installed in homes, the product history stages, institutional groups, hazard sources and countermeasures available to the CPSC. ${ }^{1}$ The relationships among these four elements was structured for evaluating alternative impacts. A review of the 1 ist of hazard sources enabled identification of five hazard sources which correspond to hazard patterns the in-depth reports indicate are involved with architectural glass accidents. The five are: (1) improper materials, (2) faulty design, (3) inadequate maintenance, (4) misuse, and (5) placement of product such that interactions creates a hazard. Having identifed hazard sources the document provides a matrix of countermeasure options available to the Commission corresponding to each hazard source. ${ }^{2}$ The scope of this phase of the project, installed annealed glass architectural products, is much narrower than the entire spectrum of products for which the matrix was developed. Those countermeasure options which could apply to architectural glass products are presented in Table 5.

The practical application of these ten countermeasures will now be discussed. The discussion will concentrate on the factors which are relevant in considering their use for implementation of safety retrofits. The ten countermeasures may be classified into three broad types of activities the Commission may consider.

(1) Mandatory activities intended to fulfill the need to protect the public through actions which set standards and either remove or modify unsafe products as warranted by the conditions;

${ }^{1}$ Stiefel, et al., Procedural Options to Reduce the Risk of Injury from Products Installed in Residences, NBSIR 75-651, June 1975, p. 9.

${ }^{2}$ Ibid., p. 22 . 
Table C. Potential Implementation Approaches for Safety Modification of Architectural Glass Products

1. Develop a product safety performance standard for retrofit materials;

2. Develop mode1 laws, regulations and standards, and encourage their uniform adoption by state and local govermments;

3. Coordinate and cooperate with other Federal agencies;

4. Encourage or effect the development and implementation of more effective maintenance and safety-oriented performance testing programs;

5. Improve information dissemination or education;

6. Require informative and truthful labeling of a product, having safety hazards;

7. Require public notice of defect or failure to comply with product safety rule, and/or require individual notice to purchasers pursuant to Section 15(c) of the Act;

8. Recall and refund monies to owner;

9. On-site alteration (retrofiting) to remedy extant defects;

10. On-site replacement to remove extant defective products. 
(2) Voluntary activities which are designed to encourage other organizations and agencies to take appropriate action perhaps leading to mandatory requirements by other agencies; and

(3) Information and education activities which are designed to bring the problem to the public's attention and offer reasonable approaches to improve safety.

\section{C.1. Mandatory Implementation Approaches}

The Commission will probably promulgate a standard for glazed architectural products in the immediate future. The standard will establish the type of glazing materials to be allowed in the hazardous locations this study addresses. In addition to establishing requirements for new products, existing products which are subsequently broken must be replaced with approved safety glazing materials. This requirement is in effect in the 32 states which have adopted the previously mentioned Mode1 Bill to Require Safety Glazing in Hazardous Locations. Still to be addressed is the question of whether to require the replacement of potentially hazardous annealed glass products before they are broken or otherwise made unsafe.

The Consumer Product Safety Act of 1972 broadly establishes the circumstances for employing the countermeasures which would either require repair, replacement or refund. A requirement to either repair a product, replace it or refund the purchase price may be imposed in cases of substantial product hazards. Section 15 (a) of the Act defines substantial product hazard as "(1) a failure to comply with an applicable consumer product safety rule which creates a substantial risk of injury to the public, or (2) a product defect which (because of the pattern of defect, the number of defective products distributed in commerce, the severity of the risk or otherwise) creates a substantial risk of injury to the public." The CPSC would have to make a finding after a hearing that either condition (1) or (2) was supported, and the public interest would be best served by ordering the manufacturer, distributor or retailer to take which ever action he elects (i.e., to repair, replace or refund the purchase of the product).

The Commission may obtain a similar result (repair, replacement or refund) through a court order by filing an action in U.S. District Court under subsection 12 (a) (2) of the Act against a manufacturer, distributor or retailer, claiming and proving commerce of an "imminently hazardous" consumer product. The Act defines this term as "a consumer product which presents imminent and unreasonable risk of death, serious illness, or severe personal injury."

Paralleling the development of a product safety standard for architectural glazing materials is the question of appropriate action for retrofit materials specifically designed to modify annealed glass products. A retrofit's effectiveness in reducing injuries depends upon a design which must: 
(1) Ameliorate the present hazard conditions leading to an injury;

(2) Perform as expected; and

(3) Not introduce a significant number of injuries through a second injury mode.

The Commission could consider setting standards for those products which are specifically designed to modify annealed glass products and thereby reduce an unreasonable risk of injury. In the case of paintedon plastics and mylar coatings, limited testing has produced inconsistent results. More information is needed. This retrofit option may be applied to nearly the entire set of architectural products at lower cost than replacement with safety glazing materials. Therefore, if the option is effective in making glass safer, it may prove to be a popular choice by safety concious consumers.

Another mandatory option the CPSC could consider is the requirement to label glazing materials. A labeling requirement for glazing materials now being sold to the public would yield two immediate results. First glazing materials not permitted for replacement, i.e., annealed glass in storm doors, could be labeled to indicate appropriate use. This would alert the consumer "do-it-yourselfer" to the hazard and would probably keep him from violating the standard. Second, it would bring to the public's attention the fact that they now have annealed glass in locations prohibited by present requirements. Such information could result in additional caution and possible replacements of or modifications to hazardous products.

Problems of improper installation and injuries resulting from installation might be ameliorated through mandatory labeling requirements. For example, adequate labeling of safety retrofit materials for annealed glass could provide information needed for safe and effective installation of these products.

\section{C.2. Voluntary Implementation Efforts}

A voluntary implementation approach on the part of CPSC may result in mandatory actions implemented by other agencies at the Federal, State and local levels of government to impact the safety of existing housing. The discussion to follow will, for each level of government, explain how the CPSC can encourage implementation of safety retrofits for architectural glass products.

\section{C.2.1. Loca1 Government}

Direct contact with each local government is impractical because of the large number of municipalities in the United States which have the authority to adopt and enforce building codes. ${ }^{3}$ The local governments

${ }^{3}$ A1len D. Manue1, Loca1 Land and Building Regulation Research Report, No. 6, National Commission on Urban Problems, 1968. 
however, rely upon several other organizations in the formulation of the codes which they adopt. For example, five model building codes have been developed through four organizations.

- Building Officials Conference of America (BOCA) - Basic Building Code

- American Insurance Association (AIA) - National Building Code

- Southern Building Code Congress (SBCC) - Southern Standard Building Code

- International Conference of Building Officials (ICBO) - Uniform Building Code

- With the cooperation of all four of the above - One and Two Family Dwelling Code

It is possible that by working with these organizations, annealed glass retrofits for existing housing could be implemented.

Several communities in Michigan, for example, have legislation which requires an inspection by building and safety departments prior to any sale of one or two family dwelling units. If units failed to meet safety and health standards, deficiencies would have to be corrected before the sale. ${ }^{5}$ The significance of the approach was that it allowed an accelerated method for increasing safety in existing housing. Use of this approach to implement safer storm doors, would perhaps require that upon resale hazardous annealed glass panels must be replaced with safety glazing or a non-glazed material.

Housing codes are another type of model code primarily related to the occupancy requirements of buildings and their maintenance after construction. Model housing codes are promulgated by the building code organizations. Because the housing codes influence accepted maintenance practices and acceptable safety levels, these codes may prove to be an excellent mechanism for increasing architectural glass safety.

In addition to the model building code organizations, there are associations of public officials which may provide CPSC a form for the introduction of ideas to increase the safety of existing housing. Many of these organizations provide advisory aids to local officials and are viewed as a source for obtaining expert advice and factual information on specific problems. Since research on current problems is an activity of many of these organizations, the CPSC may provide inputs for their research and publications. The publications of these associations include newsletters, bulletins, books, monographs, research papers, conference

${ }^{4}$ See Stiefel, W., et al., op. cit. Appendix B.4 for a discussion of mode1 building related code groups, and Appendix B. 8 for a discussion of local govermment building code regulation.

${ }^{5}$ National Safety Council, "Technical Topics Concerning Home Safety," July 1975, p. 2 . 
proceedings and regular and special reports. The following organizations may be receptive to the Comnission's ideas: ${ }^{6}$

- American Public Health Association

- International City Management Association

* National Association of Counties

- National Association of Housing and Redevelopment Officials

- National League of Cities

- National Municipal League

- U.S. Conference of Mayors

\section{C.2.2. State Government}

Like local govermment, state governments rely upon model building and housing codes in formulating their housing requirements. ${ }^{7}$ In addition, the National Conference of States on Building Codes and Standards is a form for the discussion of mutual problems and the promotion of uniformity throughout the states in building codes and their enforcement. The organization offers a point of contact with state govermment employees with building regulation responsibilities.

The CPSC's own State Conference on Product Safety offers the opportunity to make recommendations on a formal (model laws regulations and standards) or informal (idea provoking presentation) basis to encourage positive actions at the state level. Additional organizations, composed of state officials with the responsibility for legislation or administration impacting existing housing, include the Council of State Govermments, the National Legislative Conference and the National Governor's Conference.

\section{C.2.3. Federal Govermment}

Federal agencies influence housing safety both directly and indirectly. ${ }^{8}$ Direct influence is made over Federal public housing projects administered through HDD as well as housing provided to government employees, such as military housing. Direct contacts by the CPSC explaining the nature of the hazard and potential solutions could have an immediate impact. This type of housing, however, accounts for a very minor segment of U.S. housing market.

${ }^{6}$ The 1 ist was obtained from reviewing the International City Management Association's Municipal Year Book 1973, "Professional and Service Organizations Serving Loca1 and State Goverments," pp. 356-359.

${ }^{7}$ See Stiefe1, W., et al., op. cit. Appendix B.7 for a discussion of state building code enforcement.

${ }^{8}$ See Stiefe1, W., ibid., Appendix B, p. B-18 for a discussion of Federal agencies which deal with building codes and related construction matters. 
The indirect controls have a much wider influence over the private housing market. The Veterans Administration (VA) acts as a "guarantor" of mortgages let to veterans. All homes financed under VA guarantee must meet certain minimum standards, as set by that agency, and compliance is accomplished through a staff of Federal inspectors. Modifying these standards to include replacement of annealed bathtub enclosures and storm door glass, requiring visual cues for patio sliders and window walls, and proper operation of glazed doors and windows would contribute to a safer house, and is within the VA's prerogative.

The Federal Housing Administration (FHA) offers mortgage insurance for residences which meet "minimum standards (which)... assure well planned, safe, and soundly constructed homes."9 These standards, which are updated annually, are based upon current literature and past history. The VA relies heavily upon the FHA standards in formulating their own standards. Incorporation of requirements for existing architectural glazed products could accelerate the process of retrofitting or removing unsafe products from the home.

The Department of Health, Education, and Welfare's Public Health Service provides technical assistance in housing quality improvement, code administration and the training of state and (on an ad hoc basis) local agencies. Working through the Public Health Service's contacts with the various health agencies may expedite the process for influencing introduction of safety requirements for existing architectural glazing into housing codes and standards.

C.3. Informational Implementation Approaches

The purpose of an information compaign is to bring to the public's attention the hazards associated with architectural glass products. A fact which might be emphasized during any such campaign is the proportion of accidents which involve children. Such emphasis would catch the attention of parents and alert them to the possibility that although they "respect" a product, such as a storm door, their children may have no knowledge of its hazard. The Commission could consider a dual approach to attempt implementation of safety modifications through both information dissemination and education efforts.

Any education effort must recognize that the problem involves: alerting children and adults of the proper approach for using architectural glass products; influencing adults that they should take actions to make products safer; and providing information which enables concerned individuals to make products safer.

${ }^{9}$ Preface to FHA Minimum Property Standards for Multifamily Housing. 
Specific product related retrofits which are candidates for inclusion in a public information campaign:

(1) Bathtub and shower enclosures

- replacement of annealed glass with rod and shower curtain

- use of non-slip appliques and secured grab bars

(2) Storm doors

- replacement of glass with safety glazing

- replacement of glass with hardboard in lower pane1 coupled with a plate covering glass around handle

(3) Patio sliding doors

- use of visual cues such as decals, appliques and lighting

(4) All products

- keep in good working order

- immediately and properly dispose of broken glass, and

- store unused glass panels (storm windows and doors) out of traffic.

In addition to efforts designed to educate the general public, some effort is warranted to educate editors of interior design and home oriented magazines regarding the safety of architectural glass. Consumers tend to emulate the ideas presented in these magazines. The editors, for example, may be influencial in encouraging consumer use of shower curtains replacing the older annealed glass tub enclosure. Articles illustrating attractive decoration of patio sliders with decals could also contribute toward consumer acceptance of this idea. 
NBS-114A (REV. 7.73)

\begin{tabular}{|c|c|c|c|}
\hline $\begin{array}{l}\text { U.S. DEPT. OF COMM. } \\
\text { BIBLIOGRAPHIC DATA } \\
\text { SHEET }\end{array}$ & $\begin{array}{l}\text { 1. PUBLICATION OR REPORT NO. } \\
\text { NBSIR } 75-791\end{array}$ & $\begin{array}{l}\text { 2. Gov't Accession } \\
\text { No. }\end{array}$ & 3. Recipient's Accession No. \\
\hline \multirow{2}{*}{\multicolumn{3}{|c|}{$\begin{array}{l}\text { 4. TITLE ANL SUBTITLE } \\
\text { PROCEDURAL OPTIONS FOR MODIFICATION OF ARCHITECTURAL } \\
\text { GLASS IN RESIDENCES TO IMPROVE OCCUPANT SAFETY }\end{array}$}} & 5. Publication Date \\
\hline & & & 6. Performing Organization Code \\
\hline \multicolumn{3}{|l|}{ 7. AUTHOR(S) } & 8. Performing Organ. Report No. \\
\hline \multirow{2}{*}{\multicolumn{3}{|c|}{$\begin{array}{l}\text { 9. PERFORMING ORGANIZATION NAME AND ADDRESS } \\
\text { NATIONAL BUREAU OF STANDARDS } \\
\text { DEPARTMENT OF COMMERCE } \\
\text { WASHINGTON, D.C. } 20234\end{array}$}} & $\begin{array}{l}\text { 10. Project/Task/Work Unit No. } \\
4411431\end{array}$ \\
\hline & & & 11. Contract/Grant No. \\
\hline \multirow{3}{*}{\multicolumn{3}{|c|}{$\begin{array}{l}\text { 12. Sponsoring Organization Name and Complete Address (Street, City, State, ZIP) } \\
\text { Bureau of Engineering Sciences } \\
\text { Consumer Product Safety Commission } \\
5401 \text { Westbard Avenue } \\
\text { Bethesda, Maryland } 20207\end{array}$}} & $\begin{array}{l}\text { 13. Type of Report \& Period } \\
\text { Covered }\end{array}$ \\
\hline & & & Fina1 \\
\hline & & & 14. Sponsoring Agency Code \\
\hline
\end{tabular}

\section{ABSTRACT (A 200-word or less tactual summary of most significant information. If document includes a significant} bibliography or literature survey, mention it here.)

The U.S. Consumer Product Safety Commission has the responsibility for developing and promulgating mandatory safety standards for products which pose unreasonable risks of injury for consumers. One of the first products selected for development of a safety standard under the Consumer Product Safety Act of 1972 was architectural glass. The prospects for regulation of many other residential unit component parts are wide open. Nevertheless, the initial impact of the adoption of a mandatory standard for architectural glass would be rather limited. The limited impact is largely due to the fact that people will continue to occupy existing housing that will not be immediately subject to the new rule.

This report documents the second and final phase of a project which considered the possible modifications for architectural glass products and the means for encouraging their implementation. The report evaluates available injury data, defines the population of hazardous architectural glass products and compares the relative level of hazard among the products. A set of possible retrofit options is presented, suggested by accident pattern review, and criteria are developed, which are useful in assessing their effectiveness. A model has been developed and exercised to calculate benefit-cost ratios for retrofit modification based upon averted injury medical costs attributable to injuries prevented by product modification. A set of implementation approaches has been postulated for consideration by the CPSC, for encouraging safety modification of component parts of residential units.

17. KEY WORDS (six to twelve entries; alphabetical order; capitalize only the first letter of the first key word unless a proper name; separated by semicolons)

Architectural glass products; Consumer Product Safety Act; residence-related products; residential safety modification; safety implementation approaches.

18. AVAILABILITY $\quad$ Unlimited

For Official Distribution. Do Not Release to NTIS

[7 Order From Sup. of Doc., U.S. Government Printing Office Washington, D.C. 20402, SD Cat. No.C13

X Order From National Technical Information Service (NTIS) Springfield, Virginia 22151
19. SECURITY CLASS (THIS REPURT)

\begin{tabular}{|l|c|}
\hline UNCL ASSIFIED & 56 \\
\hline $\begin{array}{l}\text { 20. } \begin{array}{l}\text { SECURITY CLASS } \\
\text { (THIS P AGE) } \\
\text { UNCLASSIFIED }\end{array} \\
\text { 22. Price }\end{array}$ \\
\hline
\end{tabular}



